\title{
The Surprising Virtues of Treating Trade Secrets as IP Rights ${ }^{1}$
}

\author{
Mark A. Lemley ${ }^{2}$
}

Trade secret law is a puzzle. Courts and scholars have struggled for over a century to figure out why we protect trade secrets. The puzzle is not in understanding what trade secret law covers; there seems to be widespread agreement on the basic contours of the law. Nor is the problem that people object to the effects of the law. While scholars periodically disagree over the purposes of the law, and have for almost a century, ${ }^{3}$ they seem to agree that misappropriation

1 C 2008 Mark A. Lemley.

2 William H. Neukom Professor, Stanford Law School; of counsel, Keker \& Van Nest LLP. Thanks to Wendy Gordon, Tait Graves, Rose Hagan, David Levine, Roger Milgrim, Michael Risch and Peter Swire for discussions of these issues or comments on a prior draft. This paper does not address perhaps the most divisive issue facing the law of trade secrecy: whether it is "trade secret law" (5983 cites in Westlaw's "allcases" and "tp-all" databases combined) or "trade secrets law" (a mere 2144 cites). Westlaw search conducted Feb. 15, 2008. I use "trade secret" throughout - who am I to argue with $73.6 \%$ of all courts and commentators - but that doesn't mean I'm taking a definitive position on the issue.

3 Among the academic treatments of trade secret law and theory, see, e.g., Melvin Jager, Trade Secrets Law; Roger Milgrim, Milgrim on Trade Secrets; James H.A. Pooley, Trade Secrets; Christopher J. Rebel Pace, The Case for a Federal Trade Secrets Act, 8 Harv. J. L. \& Tech. 427, 435-42 (1995); David D. Friedman et al., Some Economics of Trade Secret Law, 5 J. Econ. Persp. 61 (1991); Gale R. Peterson, Trade Secrets in an Information Age, 32 Hous. L. Rev. 385 (1995); Edmund W. Kitch, The Law and Economics of Rights in Valuable Information, 9 J. Legal Stud. 683 (1980); David S. Levine, Secrecy and Unaccountability: Trade Secrets in Our Public Infrastructure, 59 Fla. L. Rev. 135 (2007); William B. Barton, A Study in the Law of Trade Secrets, 13 U. Cin. L. Rev. 507, 558 (1939); Note, Equitable Protection of Trade Secrets, 23 Colum. L. Rev. 164 (1923); Note, Nature of Trade Secrets and Their Protection, 42 Harv. L. Rev. 254 (1928); Charles Tait Graves, Trade Secrets as Property: Theory and Consequences, 15 J. Intell. Prop. L. 39 (2007); Michael Risch, Why Do We Have Trade Secrets?, 11 Marq. Intell. Prop. Rev. 1 (2007); Vincent Chiappetta, Myth, Chameleon, or Intellectual Property Olympian? A Normative Framework Supporting Trade Secret Law, 8 Geo. Mason L. Rev. 69 (1999); James W. Hill, Trade Secrets, Unjust Enrichment, and the Classification of Obligations, 4 Va. J. L. \& Tech. 2 (1999); Robert P. Merges, The Law and Economics of Employee Inventions, 13 Harv. J. L. \& Tech. 1, 12-31 (1999); Chris Montville, Reforming the Law of Proprietary Information, 56 Duke L.J. 1159 (2007); Sharon K. Sandeen, The Cinderella of Intellectual Property Law: Trade Secrets, in 2 Intellectual Property and Information Wealth 399 (Peter K. Yu ed. 2007); 
of trade secrets is a bad thing that the law should punish. Rather, the puzzle is a theoretical one: no one can seem to agree where trade secret law comes from or how to fit it into the broader framework of legal doctrine. Courts, lawyers, scholars, and treatise writers argue over whether trade secrets are a creature of contract, of tort, of property, or even of criminal law. ${ }^{4}$ None of these different justifications have proven entirely persuasive. Worse, they have contributed to inconsistent treatment of the basic elements of a trade secret cause of action, and uncertainty as to the relationship between trade secret laws and other causes of action. ${ }^{5}$ Robert Bone has gone so far as to suggest that this theoretical incoherence suggests that there is no need for trade secret law as a separate doctrine at all. He reasons that whatever purposes are served by trade secret law can be served just as well by the common law doctrines that underlie it, whichever those turn out to be. ${ }^{6}$

In this article, I suggest that trade secrets can be justified as a form, not of traditional property, but of intellectual property (IP). The incentive justification for encouraging new inventions is straightforward. Granting legal protection for those new inventions not only encourages their creation, but enables an inventor to sell her idea. And while we have other laws that encourage inventions, notably patent law, trade secrecy offers some significant advantages

Michael P. Simpson, Note, Trade Secrets, Property Rights, and Protectionism - an Age-Old Tale, 70 Brook. L. Rev. 1121 (2005); Jon Chally, Note, The Law of Trade Secrets: Toward a More Efficient Approach, 57 Vand. L. Rev. 1269 (2004); Note, Protection and Use of Trade Secrets, 64 Harv. L. Rev. 976 (1951); Note, Protection of Information in the Nature of Trade Secrets, 14 Minn. L. Rev. 546 (1930).

4 See infra notes ___ and accompanying text.

5 Miles J. Feldman, Toward a Clearer Standard of Protectable Information: Trade Secrets and the Employment Relationship, 9 High Tech. L.J. 151, 161-63 (1994) (arguing that much of the uncertainty in trade secret law can be traced to the disagreement over justifications for trade secret law).

6 Robert G. Bone, A New Look at Trade Secret Law: Doctrine in Search of Justification, 86 Cal. L. Rev. 241 (1998). 
for inventors over patent protection. It is cheaper and quicker to obtain, since it doesn't require government approval, and it extends to protection of types of business and process information that likely wouldn't be patentable.

It seems odd, though, for the law to encourage secrets, or to encourage only those inventions that are kept secret. I argue that, paradoxically, trade secret law actually encourages disclosure, not secrecy. Without legal protection, companies in certain industries would invest too much in keeping secrets. Trade secret law develops as a substitute for the physical and contractual restrictions those companies would otherwise impose in an effort to prevent a competitor from acquiring their information.

The puzzle then becomes why the law would require secrecy as an element of the cause of action if its goal is to reduce secrecy. I argue that the secrecy requirement serves a channeling function. Only the developers of some kinds of inventions have the option to over-invest in physical secrecy in the absence of legal protection. For products that are inherently selfdisclosing (the wheel, say, or the paper clip), trying to keep the idea secret is a lost cause. We don't need trade secret law to encourage disclosure of inherently self-disclosing products inventors of such products will get patent protection or nothing. But if trade secret law prevented the use of ideas whether or not they were secret, the result would be less, not more, diffusion of valuable information. The secrecy requirement therefore serves a gatekeeper function, ensuring that the law encourages disclosure of information that would otherwise be kept secret, while channeling inventors of self-disclosing products to the patent system.

My argument has a number of implications for trade secret policy. First, the theory works only if we treat trade secrets as an IP right, requiring proof of secrecy as an element of protection. If we give the protection to things that are public, we defeat the purpose and give 
windfalls to people who may not be inventors (what we might call "trade secret trolls"). Courts that think of trade secret law as a common law tort rather than an IP right are apt to overlook the secrecy requirement in their zeal to reach "bad actors." But it is the courts that emphasize secrecy, not appropriation, as the key element of the cause of action that have it right. Second, an IP theory of trade secrets also encourages preemption of "unjust enrichment" theories and other common-law ways courts are tempted to give private parties legal control over information in the public domain. Thus, an IP theory of trade secrets is in part a "negative" one: the value of trade secret law lies in part in defining the boundaries of the cause of action and preempting others that might reach too far. Analyzing trade secret cases as IP rights rather than common law contract or tort claims requires courts to focus on what the law is protecting, how, and why, something the common law did not do. As a result, the unified trade secret approach does not expand, but rather cabins, the overbroad reach of the common law. ${ }^{7}$ Understanding trade secrets in this negative way - as imposing a consistent set of standards on claims that would otherwise be based on disparate legal theories and claims of entitlement or free riding - advances the goals of innovation and promotes responsible business conduct without limiting the vigorous competition on which a market economy is based.

Finally, treating trade secrets as IP rights helps secure their place in the pantheon of legal protection for inventions. The traditional conception of the tradeoff between patents and trade secrets views the disclosure function of the patent system as one of its great advantages over trade secret law. And indeed the law operates in various ways to encourage inventors to choose patent over trade secret protection where both are possible. But for certain types of inventions

7 The conventional complaint is the opposite - that treating trade secrets as IP leads to overbreadth. See, e.g., Simpson, supra note _, at 1136. As I suggest in this paper, that traditional view is wrong. 
we may actually get more useful "disclosure" at less cost from trade secret than from patent law.

In Part I, I review the origins and contours of trade secret law. Part II discusses the various theories of trade secret law, and how they have split courts and commentators. In Part III, I argue that the virtue of treating trade secrets as IP rights is - or at least should be - that it limits business tort claims to circumstances in which there is really a secret to be protected, and therefore compensates for the lack of clear standards in defining what constitutes misappropriation. Finally, in Part IV I discuss the uneven internalization of this lesson in trade secrets cases to date, and some of the implications the IP theory of trade secret law has for trade secret doctrine.

\section{Trade Secret Doctrine}

\section{A. The History of Trade Secret Law}

Trade secret law is a relative latecomer to the IP pantheon. While patent and copyright law were well established in Europe by the founding of the Republic, and trademark law had common law roots in various trade doctrines, trade secret law in its modern form in AngloAmerican jurisprudence is a common law creation of the $19^{\text {th }}$ century. English and American courts first recognized a cause of action for damages for misappropriation of trade secrets in 1817 and 1837, respectively; ${ }^{8}$ injunctive relief against actual or threatened misappropriation came still later. ${ }^{9}$ These early decisions concerned issues that are still debated in trade secret cases today: the circumstances in which an employee may continue her business after departing her

8 See Newberry v. James, 35 Eng. Rep. 1011, 1013 (Ct. Ch. 1817); Vickey v. Welch, 36 Mass. 523, 527 (1837).

9 See Yovett v. Winyard, 37 Eng. Rep. 525 (Ct. Ch. 1820); Taylor v. Blanchard, 95 Mass. 370 (1866). 
employer, the circumstances in which a competitor may copy another's publicly sold product, and whether courts will enforce a contract requiring that business information be kept confidential. While there were forms of trade secret protection on the continent dating perhaps as far back as Roman times, ${ }^{10}$ modern trade secret law is primarily an Anglo-American doctrine. Indeed, even today trade secret law is not well established outside of common law countries, ${ }^{11}$

10 One scholar traces the earliest legal protection against "misappropriation of trade secrets" to the Roman empire. See A. Arthur Schiller, Trade Secrets and the Roman Law: The Actio Servi Corrupti, 30 Colum. L. Rev. 837 (1930). The Roman courts created a cause of action called "actio servi corrupti" - literally, an action for corrupting a slave. According to Schiller, the actio servi corrupti was used to protect slave owners from third parties who would "corrupt" slaves (by bribery or intimidation) into disclosing their owners' confidential business information. The law made such third parties liable to the slave owner for twice the damages he suffered as a result of the disclosure.

While more recent scholarship has cast some doubt on the enforcement of trade secret protection in the Roman empire, see Alan Watson, Trade Secrets and Roman Law: The Myth Exploded, 11 Tul. Eur. \& Civ. L.F. 19 (1996), the concept that so-called business or "trade secrets" were entitled to legal protection spread rapidly throughout the world. As early as the Renaissance, most European nation-states had laws that protected businesses (notably, the Guild cartels) from those who used their secret processes and ideas without permission. These early laws were translated during the Industrial Revolution into statutes that protected "industrial secrets." Many of these statutes are still in force today, albeit in modified form.

The roots of trade secrecy in slavery law were further evident in the treatment of employees in the centuries before the Industrial Revolution. Both commerce and foreign policy included a strong dose of "mercantilism." Governments and private guilds attempted to keep "their" intellectual property within their grasp, using a combination of rewards to inventors and rules that reduced employee mobility. These developments are well traced in Carlo M. Cipolla, Before the Industrial Revolution: European Economy and Society 1000-1700 (2d ed. 1980); David J. Jeremy, Transatlantic Industrial Revolution: The Diffusion of Textile Technologies Between Britain and America, 1790-1830's, at 185-189 (MIT Press 1981). The authors provide such examples as restrictive British secrecy laws, city rewards to woolen craftsmen in thirteenthcentury Bologna and, on the other side, the kidnapping of skilled Swedish ironworkers by France in 1660. See Robert P. Merges et al., Intellectual Property in the New Technological Age 34 (Rev. $4^{\text {th }}$ ed. 2007).

11 Japan has only recently enacted a trade secret protection statute. See Hideo Nakoshi, New Japanese Trade Secret Act, 75 J. Pat. \& Trademark Off. Society 631 (1993). Nakoshi provides some interesting thoughts on why Japan considered such a trade secret statute unnecessary for so long. He argues that cultural norms of assumed trust made it socially uncomfortable to insist on formal confidentiality agreements, and that long-term or lifetime employment eliminated many trade secret issues associated with employee mobility. 
notwithstanding treaties that require most countries of the world to implement trade secret protection. $^{12}$

The doctrine of trade secrets evolved out of a series of related common-law torts: breach of confidence, breach of confidential relationship, common-law misappropriation, unfair competition, unjust enrichment, and torts related to trespass or unauthorized access to a plaintiff's property. It also evolved out of a series of legal rules - contract and common law governing the employment relationship. In the $19^{\text {th }}$ Century, courts periodically spoke of trade secrets as property rights, though it is not clear that they meant by that term what we mean today. ${ }^{13}$ By the early $20^{\text {th }}$ Century, the paradigm had shifted, and misappropriation of trade secrets was treated as a tort based on the confidential relationship between the parties or the misbehavior of the defendant. ${ }^{14}$ The standards for trade secret law were collected in the Restatement of Torts in $1939,{ }^{15}$ and that Restatement was strongly of the view that trade secrets were not property rights but torts based on bad faith competitive conduct. By the 1980 s, a view of trade secrets as based in some combination of contracts and property was on the ascendancy, both the Supreme Court $^{16}$ and in state legislatures, the overwhelming majority of which have adopted the Uniform Trade Secrets Act in the last 25 years.

12 General Agreement on Tariffs and Trade, Trade Related Aspects of Intellectual Property (TRIPs) art. 39 (1994).

13 On the role of the term "property" in IP rights throughout history see, for example, Adam Mossoff, Who Cares What Thomas Jefferson Thought About Patents? Reevaluating the Patent 'Privilege' in Historical Context, 92 Cornell L. Rev. 953 (2007); Justin Hughes, Copyright and Incomplete Historiographies: Of Piracy, Propertization, and Thomas Jefferson, 79 S. Cal. L. Rev. 993 (2006). But as I note below, "property” in the Nineteenth Century meant something rather different than most people understand it today, so one must be cautious about drawing meaning from labels.

14 E.I. du Pont \& Co. v. Masland, 244 U.S. 100, 102 (1917).

15 Restatement of Torts $\S 757$ (1939). 


\section{B. The Scope of Trade Secret $\mathrm{Law}^{17}$}

A trade secret claim can be broken down into three essential elements. First, the subject matter involved must qualify for trade secret protection: it must be the type of knowledge or information that trade secret law was meant to protect, and it must not be generally known to those in the industry. On eligible subject matter, the current trend, exemplified once again by the UTSA, is to protect any valuable information as a trade secret. So long as the information is capable of adding economic value to the plaintiff, it can be protected by trade secret law. The requirement that the information not be generally known follows from the label trade secret. The requirement is meant to ensure that no one claims intellectual property protection for information commonly known in a trade or industry. ${ }^{18}$

The second element to be established by the plaintiff in a trade secret case is that the plaintiff, holder of the trade secret, took reasonable precautions under the circumstances to prevent its disclosure. Courts have shown some confusion over the rationale for this requirement. Some see in it evidence that the trade secret is valuable enough to bother litigating; others argue that where reasonable precautions are taken, chances are that a defendant acquired the trade secret wrongfully. ${ }^{19}$ Whatever the justification, it is clear that no one may let information about

16 Ruckelshaus v. Monsanto Co., 467 U.S. 986, 1001-04 (1984).

17 The first four paragraphs of this subsection are adapted from Merges et al., supra note _ , at 37.

18 For discussion of the problem of once-secret information disclosed on the Internet, see, e.g., Elizabeth A. Rowe, Introducing a Takedown for Trade Secrets on the Internet, 2007 Wis. L. Rev. 1041. For an interesting legislative effort to hold back the tide, see Nev. Rev. Stat. 600A.030 (defining information released on the Internet as "secret" for purposes of trade secret law if the owner succeeds in getting it removed within a reasonable time).

19 See, e.g., Rockwell Graphic Sys., Inc. v. DEV Indus., 925 F.2d 174 ( $7^{\text {th }}$ Cir. 1991). 
products and operations flow freely to competitors at one time and then later claim that competitors have wrongfully acquired valuable trade secrets. To establish the right to sue later, one must be reasonably diligent in protecting information. As always, however, the presence of the term "reasonable" ensures close cases and difficult line-drawing for courts, and it is clear that only some precautions, not completely effective ones, are required.

Finally, a trade secret plaintiff also must prove that the defendant acquired the information wrongfully — in a word, that the defendant misappropriated the trade secret. Just because a person's information is valuable does not make it wrong for another to use it or disclose it. But use or disclosure is wrong, in the eyes of trade secret law, when the information is acquired through deception, skullduggery, or outright theft. Close cases abound in this area, not simply because of the creativity of competitors in rooting out information about their rivals' businesses and products but because the concept of misappropriation is itself ill-defined.

In many cases a defendant's use or disclosure is wrongful because of a preexisting obligation to the plaintiff not to disclose or appropriate the trade secret. Such an obligation can arise in either of two ways: explicitly, by contract; and implicitly, because of an implied duty. A classic example of an implied duty is the case of an employee. Even in the absence of an explicit contract, most employees are held to have a duty to protect their employers' interests in the employers' secret practices, information, and the like. Even where the duty arises by explicit contract, however, public policy limitations on the scope and duration of the agreement will often come into play, in some cases resulting in substantial judicial modification of the explicit obligations laid out in the contract.

Trade secrets cases come up in three basic sets of circumstances: competitive intelligence, business transactions, and departing employees. The intelligence-gathering cases 
define rights between strangers, usually competitors, when the defendant engages in some conduct designed to learn of information in the possession of the plaintiff. Some amount of competitive intelligence-gathering is permissible, but courts have said that if that activity exceeds some (relatively ill-defined) bounds of commercial morality it is misappropriation of trade secrets. Often those cases will involve violations of some other law. But that is not always true. In DuPont v. Christopher, for example, the court held that the defendant misappropriated secrets by taking aerial photographs of the plaintiff's chemical engineering plant while it was under construction. ${ }^{20}$ There was no law preventing the Christophers from flying where they were, or taking pictures, but in the court's view it was a "schoolboy trick" that trade secret law should not permit. ${ }^{21}$ Not surprisingly, the genesis of these cases is in tort (and, to a lesser extent, criminal) law, which traditionally governs relations between strangers.

The business transaction and departing employee cases, by contrast, involve parties who have been in a business relationship, or at least a negotiation towards a business relationship. As a result, the trade secrets rules in these cases tend to derive from contract law. Sometimes this is express: the question the court considers is whether negotiating parties signed a nondisclosure agreement, or whether an employee signed an employment agreement restricting the use or disclosure of trade secrets. In other cases, courts are willing to imply restrictions on the use of confidential information created or disclosed in such a relationship even in the absence of a contract. In Smith v. Dravo, for example, the court implied a confidentiality restriction when the plaintiff disclosed confidential information to the defendant, who was considering buying

20 E.I. DuPont deNemours \& Co. v. Christopher, 431 F.2d 1012 (5 $5^{\text {th }}$ Cir. 1970).

${ }^{21} I d$. at . Some question whether courts would reach the same result today, see Kevin Werbach, Sensors and Sensibilities, 28 Cardozo L. Rev. 2321, 2348-49 (2007), but that is because technology has changed expectations of privacy, not because the application of trade secret law to third parties has changed. 
plaintiff's company. ${ }^{22}$ The departing employee cases take the same form, though in the modern world it is rare that such employees don't have an employment contract. As with the competitive intelligence cases, trade secret law takes a basic common law principle (there tort, here contract) and supplements it in certain cases in the interest of fairness.

Misappropriation of trade secrets, then, does not simply require use of a trade secret, but acquisition, use or disclosure of a secret in a way that runs afoul of the prohibitions of trade secret law. Further, some conduct will be protected even if it discloses a trade secret. For example, a defendant who acquires a trade secret by developing it on her own or by reverse engineering it is free to do what she wants with the secret.

Proof of trade secret misappropriation gives rise to a panoply of remedies whose origin is as diverse as the original sources of trade secret law. Depending on the circumstances, trade secret owners can obtain criminal penalties (a remedy based in criminal law), an injunction (a remedy that sounds in property law), damages measured by the greater of the owner's loss or the defendant's gain (a remedy based in tort law), or a limited "head start" injunction ${ }^{23}$ designed to put the parties back in the same situation they would have been in had the misappropriation not occurred (a remedy that sounds in the expectation damages rule of contract law).

\section{Efforts to Understand Trade Secret Theory}

Legal protection for trade secrets has been premised primarily on two theories that are only partly complementary. The first is utilitarian. Under this view, protecting against the theft of

22 Smith v. Dravo Corp., 203 F.2d 369 ( $7^{\text {th }}$ Cir. 1953).

23 A "head start" injunction precludes the defendant from working on a project for a limited period of time, to put it back in the position it would have occupied had misappropriation of the plaintiff's trade secrets not given it a head start on competition. See, e.g., Winston Res. Corp. v. 3M Corp., 350 F.2d 134 ( $9^{\text {th }}$ Cir. 1965). 
proprietary information encourages investment in such information. This idea is sometimes associated with the view that trade secrets are a form of property. The second theory emphasizes deterrence of wrongful acts and is therefore sometimes described as a tort theory. Here the aim of trade secret law is to punish and prevent illicit behavior, and even to uphold reasonable standards of commercial behavior. ${ }^{24}$ Although under the tort theory trade secret protection is not explicitly about encouraging investments, it is plain that one consequence of deterring wrongful behavior would be to encourage investment in trade secrets. Hence, despite their conceptual differences, the tort and property/incentive approaches to trade secrets may well push in the same direction in many respects.

\section{A. Tort Law}

A primary explanation for trade secret law throughout the $20^{\text {th }}$ Century is what might be described as a "duty-based" theory, or what Melvin Jager calls "the maintenance of commercial morality." 25 The Supreme Court adopted this view in a famous early decision, albeit one that bore only a tangential relationship to trade secret law:

The word "property" as applied to trademarks and trade secrets is an unanalyzed expression of certain secondary consequences of the primary fact that the law makes some rudimentary requirements of good faith. Whether the plaintiffs have any valuable secret or not, the defendant knows the facts, whatever they are, through a special

24 Cf. Kim Lane Scheppele, Legal Secrets: Equality and Efficiency in the Common Law (1988) (arguing that cases involving legal secrets - including trade secrets cases - are better explained in terms of principles all would be willing to agree to rather than in the efficiency terms of law and economics).

251 Jager, supra note _ , §1.03, at 1-4. 
confidence that he accepted. The property may be denied, but the confidence cannot be.

Therefore the starting point for the present matter is not property or due process of law, but that the defendant stood in confidential relations with the plaintiffs.... ${ }^{26}$

This tort-based view gained significant currency at the beginning of the $20^{\text {th }}$ Century, in part because of Masland but also because of changing conceptions of property. ${ }^{27}$ By 1939 , the American Law Institute firmly classed trade secret law as a tort, including it in the Restatement of Torts. ${ }^{28}$ It is also frequently invoked today by scholars seeking to justify trade secret law, ${ }^{29}$ and sometimes by those who believe the tort approach will help limit it. ${ }^{30}$ The ultimate expression of the tort view would replace trade secrets entirely with a general tort of wrongful misappropriation of information. ${ }^{31}$

26 E.I. du Pont \& Co. v. Masland, 244 U.S. 100, 102 (1917). The actual issue in Masland was whether the trial court had discretion to prohibit disclosure of the secret to an outside expert during litigation. Pooley, supra note _, sec. 1.02[8][b], at 1-16.

The Monsanto Court attempted to distinguish Masland in a footnote, claiming that "Justice Holmes did not deny the existence of a property interest; he simply deemed determination of the existence of that interest irrelevant to the resolution of the case."Monsanto, 467 U.S. 1004 n.9. This seems a weak argument; the point of Masland was that the plaintiff did not need a property right in order to obtain relief under the trade secret laws. That is a point at fundamental odds with the property theory of trade secrets.

27 See also Eastman Co. v. Reichenbach, 20 N.Y. Supp. 110, 115-16 (1892).

28 Restatement of Torts $\S 757,758$ (1939). Notably, the ALI had abandoned that position by the time the Second Restatement was published in 1979, on the grounds that the law of trade secrets had developed into an independent body of law that no longer relied on general principles of tort law.

29 See, e.g.., Hill, supra note _, at 2; cf. Chiappetta, supra note _, at _ (dividing trade secret law into distinct categories, including some based on unjust enrichment or contract law); Lynn Sharp Paine, Trade Secrets and the Justification of Intellectual Property: A Comment on Hettinger, 20 Phil. \& Pub. Aff. 247 (1991).

30 See, e.g., Pamela Samuelson, Cyberspace and Privacy: A New Legal Paradigm? Privacy as Intellectual Property, 52 Stan. L. Rev. 1125, 1153 (2000).

31 For such a proposal, see C. Own Paepke, An Economic Interpretation of the Misappropriation Doctrine: Common Law Protection for Investments in Innovation, 2 High 
The problem with the tort view is that it is ultimately empty. It presupposes a wrong without offering any substantive definition of what that wrong is. In Masland, it appears to be the breach of a confidential relationship that is the problem. Masland is not alone: many trade secret cases arise out of a "duty" explicitly stated in a contract, such as a technology license or an employment agreement. But if that is the wrong, trade secret law is nothing more than contract law. ${ }^{32}$ The tort-based theory of breach of duty merges in those cases with a standard common law action for breach of contract, express or implied. Calling this breach a trade secrets claim merely adds a stronger panoply of remedies for what is in essence a breach of contract claim. And if the gravamen of trade secrets misappropriation is nothing more than contract, why would we want to make breach of that contract a crime?

The problem of lack of substantive guidelines becomes more acute with the "improper means" prong of trade secret law. It is unhelpful for courts to say no more than that people cannot act "improperly" in acquiring information. If by "improper means" the law intends nothing more than that acts already illegal (hacking, trespass, theft) are illegal here as well, then it has the same problem as the breach of confidence prong: trade secret law adds nothing to existing doctrine. ${ }^{33}$ But most people think improper means encompasses more. In $d u$ Pont $v$. Christopher ${ }^{34}$ for example, the court found photographers liable for flying above a chemical plant under construction and taking pictures of the design of the plant, because the pictures could

Tech. L.J. 55, 69 (1987).

32 Robert Bone makes this point. Bone, supra note _, at 244. See also David A. Rice, Public Goods, Private Contract, and Public Policy: Federal Preemption of Software License Prohibitions Against Reverse Engineering, 53 U. Pitt. L. Rev. 543, 622 (1992) ("Contract plays a critical role in trade secret protection.").

33 Bone, supra note _, at 298-99.

34 E.I. DuPont deNemours \& Co. v. Christopher, 431 F.2d 1012 (5 $5^{\text {th }}$ Cir. 1970). 
disclose secrets concerning the process that would be implemented in the plant. The court acknowledged that the Christophers had broken no law. Nonetheless, the court found that their “schoolboy's trick" was improper. The court doesn't offer a particularly clear standard, however:

In taking this position we realize that industrial espionage of the sort here perpetrated has become a popular sport in some segments of our industrial community. However, our devotion to free-wheeling industrial competition must not force us into accepting the law of the jungle as the standard of morality expected in our commercial relations. Our tolerance of the espionage game must cease when the protections required to prevent another's spying cost so much that the spirit of inventiveness is dampened. Commercial privacy must be protected from espionage which could not have been reasonably anticipated or prevented. We do not mean to imply, however, that everything not in plain view is within the protected vale, nor that all information obtained through every extra optical extension is forbidden. Indeed, for our industrial competition to remain healthy there must be breathing room for observing a competing industrialist. A competitor can and must shop his competition for pricing and examine his products for quality, components, and methods of manufacture. Perhaps ordinary fences and roofs must be built to shut out incursive eyes, but we need not require the discoverer of a trade secret to guard against the unanticipated, the undetectable, or the unpreventable methods of espionage now available.

In the instant case DuPont was in the midst of constructing a plant. Although after construction the finished plant would have protected much of the process from view, during the period of construction the trade secret was exposed to view from the air. To 
require DuPont to put a roof over the unfinished plant to guard its secret would impose an enormous expense to prevent nothing more than a school boy's trick. .. ${ }^{35}$

While there is a standard here - the court will judge the relative costs of protection and of espionage - it is not one that is predictable or easy to implement.

That vagueness in itself wouldn't necessarily be a problem; we have vague standards in other areas of law where needed to achieve efficient results. And some would argue that the case itself is sui generis. But the $d u$ Pont case begs a larger question: why is it bad to acquire information in this way? We don't always or even often punish efforts to obtain competitive intelligence through legal means. One reading $d u$ Pont's standard might reasonably wonder, for example, why reverse engineering a chemical, or learning a competitor's prices by walking through their store during business hours, or attempting to predict a competitor's business strategy based on their market behavior aren't similarly cheap efforts to acquire knowledge that would be expensive to protect. And yet those activities are clearly legal.

The courts applying the tort standard are effectively defining certain acts as "unfair competition" or "free riding." But there is a growing tendency in the courts to treat the term "unfair competition" as redundant, using the doctrine to punish aggressive competition in the name of protecting "fair" business practices. Without some reason to protect a secret, the tort theory of secrecy is likely to devolve into challenges to a variety of competitive informationgathering, with courts unable to resolve those challenges on any principled basis, instead making ad hoc judgments based on their perception of the defendant's intent. ${ }^{36}$ And that in turn leaves a

35 Id. at

36 Something similar has arguably happened in trademark law, where the multifactor likelihood of consumer confusion test - designed to evoke and rely upon consumer perceptions of the marks - has in practice devolved into an inquiry primarily focused on the judge's perception of 
zone of uncertainty around business behavior that is likely to discourage robust competition by companies who fear that competition may later be deemed unfair. It may also have similar deterrent effects on departing employees: courts are more likely to impose obligations on departing employees and to punish those deemed to have acted unfaithfully if it views "bad acts" and breach of contract as the central justifications for trade secret law. ${ }^{37}$

\section{B. Contract Law}

Court or commentators have periodically suggested that trade secret law is (or more commonly, should be) coextensive with contract. ${ }^{38}$ The problems with contract as a stand-alone explanation for trade secret law are two-fold. First, contract theory cannot explain an important subset of trade secret cases: those determining legal rights between strangers. This includes not only the improper means cases, but also those in which a trade secret is acquired by accident or mistake, ${ }^{39}$ and those in which liability extends not merely to those in privity with the trade secret

the defendant's intent in adopting the mark. See Barton Beebe, An Empirical Study of the Multifactor Tests for Trademark Infringement, 94 CAL. L. REV. 1581, 1623-31 (2006) (demonstrating this empirically). For the problems that creates, see Stacey L. Dogan \& Mark A. Lemley, Grounding Trademark Law Through Trademark Use, 92 Iowa L. Rev. 1669, 1692 (2007) ("The trademark owners that have succeeded in holding defendants liable for nontrademark uses have done so by claiming that the defendant engaged in "free riding." But permissible free riding is everywhere. Since we lack any normative baseline for defining what forms of free riding should be forbidden, the likelihood-of-confusion test standing alone cannot establish any limits on the ability of trademark owners to forbid a new category of uses.")

37 Graves, supra note _, at 45-46, makes this point.

38 See Thornton Robison, The Confidence Game: An Approach to the Law About Trade Secrets, 25 Ariz. L. Rev. 347 (1983); Melvin Jager, Trade Secret Law § 4.01[1] (discussing contract theories of trade secret law). Cf. ConFold Pacific, 433 F.3d at 959 (reading trade secret law as dictated by a combination of contract and tort); Edmund W. Kitch, Intellectual Property and the Common Law, 78 Va. L. Rev. 293 (1992) (arguing that contract underlies IP more generally). 
owner but those who deal with one who is in privity. ${ }^{40}$ At best, then, contractual relations could be only a partial explanation for trade secret law. ${ }^{41}$ Second, even in the subset of cases dealing with parties in a contractual relationship, contract theory cannot explain the various ways in which trade secret law departs from enforcing the bargain those courts have struck. ${ }^{42}$ Nor can a contract theory explain the strong remedies afforded trade secret owners. In no other area of contract law do we impose criminal penalties.

\section{Property Rights}

The most significant competing theory of trade secrets is that they are property rights, something owned because possessed by the trade secret plaintiff. This seems to have been a commonly held view in the $19^{\text {th }}$ Century, ${ }^{43}$ though analysis of the early cases is complicated by the fact that the label "property" at that time meant something rather different than it means to many people today, and often little more than that the right was to be protected by the injunctive power of courts in equity (the "property rule"). ${ }^{44}$ After a period in which the property approach took a back seat to misappropriation theory, the Supreme Court resurrected the property view of

40 Id. sec. 1(2)(ii)(B). On this problem, see Dan L. Burk, Intellectual Property and the Firm, 71 U. Chi. L. Rev. 3 (2004); Oren Bar-Gill \& Bideon Parchomovsky, Intellectual Property Law and the Boundaries of the Firm (working paper 2004) (adopting Burk's framework). Cf. Robert P. Merges, The Law and Economics of Employee Inventions, 13 Harv. J. L. \& Tech. 1 (1999) (adopting a theory of the firm approach to employee inventions).

41 For a discussion of the differences between trade secret law and contract law, see Alan J. Tracey, The Contract in the Trade Secret Ballroom - A Forgotten Dance Partner?, 16 Tex. Intell. Prop. L.J. 47, 69-79 (2007).

42 I discuss those ways, and their importance, infra notes ___ _ and accompanying text.

43 See Peabody v. Norfolk, 98 Mass. 452, 458 (1868). For a critical analysis of the history of trade secrets as property, see Miguel Deutch, The Property Concept of Trade Secrets in AngloAmerican Law: An Ongoing Debate, 31 U. Rich. L. Rev. 313 (1997). 
trade secret law in Ruckelshaus v. Monsanto Co. ${ }^{45}$ There the Court faced the question of whether a federal law that required Monsanto to publicly disclose its trade secrets was a "taking of private property" for which the Fifth Amendment required compensation. The Court, in finding that trade secrets could be "property" protected by the Constitution, reasoned in part that "[t]rade secrets have many of the characteristics of more tangible forms of property. A trade secret is assignable. A trade secret can form the res of a trust, and it passes to a trustee in bankruptcy." Many have argued that the Uniform Trade Secrets Act ushered in a property view of trade secrets as well. ${ }^{47}$

Treating trade secrets as property begs the question of why the government has created such property, however. After all, these secrets have not been protected since time immemorial. Nor are they rivalrously consumed, so that absent legal protection the information that is the basis of

44 Robert Bone discusses the $19^{\text {th }}$ Century history in detail. See Bone, supra note , at 251-59.

45467 U.S. 986, 1001-1004 (1984). For property-based defenses of trade secret law, see, e.g., Graves, supra note _, at 41-42; Miguel Deutch, The Property Concept of Trade Secrets in Anglo-American Law: An Ongoing Debate, 31 U. Rich. L. Rev. 313, 320 (1997); Adam Mossoff, What Is Property? Putting the Pieces Back Together, 45 Ariz. L. Rev. 371 (2003); Pace, supra note _, at 428. For criticisms of the property conception in general, and Ruckelshaus in particular, see Pamela Samuelson, Information as Property: Do Ruckelshaus and Carpenter Signal a Changing Direction in Intellectual Property Law, 38 Cath. U. L. Rev. 365, 374-75 (1989).

46 Id. at 1002-1004. To the same effect is Phillip Morris v. Reilly, 312 F.3d 24 ( $\left(1^{\text {st }}\right.$ Cir. 2002) (en banc) (state regulation requiring disclosure of the content of cigarettes was a regulatory taking of trade secrets). See also Cadence Design Sys., Inc. v. Avant! Corp., 127 Cal. Rptr. 2d 169 (Cal. 2002); DVD Copy Control Ass'n v. Bunner, 4 Cal. Rptr. 3d 69, 84-85 (Cal. 2003) (trade secrets represent "a constitutionally recognized property interest in information"); E.I. du Pont de Nemours \& Co. v. United States, 288 F.2d 904, 912 (Ct. Cl. 1961); 1 Milgrim, supra note _, at sec. 2.01[1]-[2] ("Practically all jurisdictions have recognized that a trade secret is property" at least in certain senses); Richard A. Epstein, The Constitutional Protection of Trade Secrets Under the Takings Clause, 71 U. Chi. L. Rev. 57, 61 (2004).

47 See, e.g., Lyyn C. Tyler, Trade Secrets in Indiana: Property vs. Relationship, 31 Ind. L. Rev. 339 (1998). 
the protection would be "overused" like a commons might be overgrazed. ${ }^{48}$ Courts made a decision to grant protection, something that rarely happens with other forms of property. ${ }^{49}$ Further, while secrecy is a requirement of protection, courts make it clear that trade secret owners do not have to maintain perfect secrecy. They are free to market products incorporating the secret, and to disclose the secret itself to others in the service of making money. ${ }^{50}$ The "property," then, is not merely a right to exclude others from something in the sole possession of the plaintiff, but a right to restrict the access, use and disclosure of information that is actually or potentially in the possession of others, often through the action of the secret owner herself.

References to a "property" right in trade secret law, therefore, seem in fact not to mean that non-public information is similar to real or chattel property, but instead to mean that trade secrets should be treated as an IP right. ${ }^{51}$ The trade secret owner is entitled to control certain

48 See Garrett Hardin, The Tragedy of the Commons, 162 Science 1243 (1968). Some scholars have argued that information isn't a public good, and therefore is subject to the tragedy of the commons, because its value may depend on secrecy. See Amitai Aviram \& Avishalom Tor, Overcoming Impediments to Information Sharing, 55 Ala. L. Rev. 231, 234-35 (2004). But that argument confuses the intrinsic value and characteristics of the information with the private value that may result from the legal decision to protect that information as a secret. For further discussion, see Lemley, Free Riding, supra note _, at n. 87.

49 While trade secret law is now statutory in most states, it originally developed as common law in all of them.

50 See, e.g., Metallurgical Indus. v. Fourtek, Inc., 790 F.2d 1195 (5 ${ }^{\text {th }}$ Cir. 1986).

51 Bone makes much of the fact that trade secrets, unlike other forms of IP rights, are limited to relations between parties. Bone, supra note _, at 244. But I think he overstates both the limits on trade secret law - it reaches beyond the bounds of any formal relationship to punish some conduct vis-à-vis strangers - and the nature of IP rights. Copyright in particular requires copying, and therefore a "relationship" with the plaintiff's subject matter in just the same way trade secret law does. $C f$. Risch, supra note property" and "substantive property" rights). (discussing a distinction between "collateral

Whether IP rights should be thought of as property rights is a matter of some dispute. It seems clear that IP rights differ in fundamental respects from land and other forms of tangible property. See, e.g., Mark A. Lemley, Property, Intellectual Property, and Free Riding, 83 Tex. L. Rev. 1031 (2005). A number of scholars have argued that the concept of property is much 
information even once it has left the owner's possession. Why? "Because I possess it" cannot be the answer. The answer instead must be instrumental: we grant rights over secret information for the same reason we grant rights in patent and copyright law - to encourage investment in the research and development that produces the information. ${ }^{52}$

Treatment of trade secrets as property rights vested in the trade secret "owner" is consistent with a view of trade secret law as providing an additional incentive to innovate beyond those provided in patent law. Trade secrets protect types of information that are not eligible for patent protection. They also provide immediate protection, while it takes years to get a patent. The Supreme Court has offered some support for this incentive view in cases such as Kewanee Oil Co. v. Bicron Corp. ${ }^{53}$ But protecting secrecy seems an odd way of encouraging

broader than its tangible instantiations, and that it should include IP rights even though they are properly treated very differently than other forms of property. See, e.g., Michael A. Carrier, Cabining Intellectual Property Through a Property Paradigm, 54 Duke L.J. 1 (2005); Richard A. Epstein, Intellectual Property: Old Boundaries and New Frontiers, 76 Ind. L.J. 803, 804 (2001); but see Stewart E. Sterk, Intellectualizing Property: The Tenuous Connections Between Land and Copyright, 83 Wash. U.L.Q. 417 (2005); Peter S. Menell, The Property Rights Movement's Embrace of Intellectual Property: True Love or Doomed Relationship?, 34 Ecology L.Q. 713 (2007). For purposes of this article, it doesn't matter whether IP is property. It is sufficient to say that when trade secret courts speak of property, what they mean is IP.

52 Richard Epstein conceives of trade secrets as property, but minimizes the difference between real property and IP. Richard A. Epstein, The Constitutional Protection of Trade Secrets Under the Takings Clause, 71 U. Chi. L. Rev. 57, 58 (2004). My disagreements with the latter point are set out in detail elsewhere. See Lemley, Free Riding, supra note _, at _.

53416 U.S. 470, 481-485 (1974). In Kewanee, the Court held that:

Certainly the patent policy of encouraging invention is not disturbed by the existence of another form of incentive to invention. In this respect the two systems are not and never would be in conflict....

Trade secret law will encourage invention in areas where patent law does not reach, and will prompt the independent innovator to proceed with the discovery and exploitation of his invention. Competition is fostered and the public is not deprived of the use of valuable, if not quite patentable, invention. 
innovation. As a result, a number of commentators have suggested that if trade secret law is an IP right, it is a misguided one. ${ }^{54}$

\section{Commercial Morality and Other Theories}

While the IP and tort theories have predominated in judicial decisions and scholarly commentary, commentators and occasional courts have offered other theories in an attempt to unify and justify trade secret law. ${ }^{55}$ Most notable is the oft-quoted justification that trade secret law is designed to maintain "standards of commercial morality." would embed in legal doctrine the common standards of behavior, either across industries or varying the law industry-by-industry. ${ }^{57}$

Id. at

54 Bone, for example, argues that there is no evidence we need the additional incentive provided by trade secret law in areas patent does not reach, and that that incentive comes at too great a cost. Bone, supra note _, at 266-70. As I explain in Part III, I believe Bone is mistaken about the choice set facing technology companies absent trade secret law, and accordingly about the relative costs of having and not having that law.

55 See, e.g., Bruce T. Atkins, Trading Secrets in the Information Age: Can Trade Secret Law Survive the Internet?, 1996 U. Ill. L. Rev. 1151 (arguing for a reconception of trade secrets as a privacy right). Ironically, Sharon Sandeen argues for the reverse - rethinking privacy as a trade secret right. Sandeen, supra note _, at _.

56 E.I. DuPont deNemours \& Co. v. Christopher, 431 F.2d $1012\left(5^{\text {th }}\right.$ Cir. 1970) (refusing to accept "the law of the jungle as the standard of morality expected in our commercial relations"); Hyde Corp. v. Huffines, 314 S.W.2d 763, 773 (Tex. 1958) ("the undoubted tendency of [trade secret] law has been to recognize and enforce higher standards of commercial morality in the business world"); Jet Spray Cooler, Inc. v. Crampton, 385 N.E.2d 1349, 1354-55 (Mass. 1979) (the law encourages trade secrets because of the public interest "in the maintenance of standards of commercial ethics"); 1 Jager, supra note _, §1.03, at 1-4; Restatement of Torts sec. 757, cmt. f at 10 (1939) (improper means are those "which fall below the generally accepted standards of commercial morality and reasonable conduct."); Chiappetta, supra note _, at _ (defending trade secret law in part as directed against torts that "threaten public order"); Harry Wingo, Dumpster Diving and the Ethical Blindspot of Trade Secret Law, 16 Yale L. \& Pol'y Rev. 195 (1997).

57 On the historical role of commercial morality in trade secret law, see Catherine L. Fisk, Working Knowledge: Trade Secrets, Restrictive Covenants in Employement, and the Rise of 
Unfortunately, the commercial morality approach doesn't cure the defects of tort-based theories of trade secrecy. "Commercial morality" has no more substantive content than "unfair competition" or "unjust enrichment" - it still requires some external source to determine what behavior is and is not moral. ${ }^{58}$ To be sure, the commercial morality approach does at least point us to an external source - the emergent consensus (if there is one) of what constitutes acceptable behavior. But relying on such a vague norm to set legal standards has a number of problems. It is context and time-dependent; normal behavior in one industry may end up being illegal in another. Those norms may change over time in ways that make protection unpredictable; flying over a chemical plant to see how it was laid out was improper in $1970,{ }^{59}$ but one might reasonably doubt that looking at satellite photos of the same plant on Google Earth would be illegal today. It requires courts to engage in what Stephen Carter has called "judicial anthropology, ${ }^{, 60}$ an endeavor at which they may not be particularly skilled. It is likely to lead to inefficient results, retarding rather than enhancing innovation. ${ }^{61}$ And its inherent vagueness may create due process problems, particularly when trade secret law is enforced through criminal sanctions. In any event, it may be honored only in the breach: one study found no evidence that

Corporate Intellectual Property, 1800-1920, 52 Hastings L.J. 441 (2001).

58 Interestingly, Yuval Feldman has conducted surveys suggesting that departing employees are in fact motivated by their beliefs both as to what is moral and, more importantly, what their new employer would consider legitimate. See Yuval Feldman, The Behavioral Foundations of Trade Secrets: Tangibility, Authorship, and Legality, 3 J. Empirical Leg. Stud. 197 (2006).

59 E.I. DuPont deNemours \& Co. v. Christopher, 431 F.2d $1012\left(5^{\text {th }}\right.$ Cir. 1970).

60 Stephen L. Carter, Custom Adjudication, and Petrushevsky's Watch: Some Notes From the Intellectual Property Front, 72 Va. L. Rev. 129 (1992); see also Jennifer E. Rothman, The Questionable Use of Custom in Intellectual Property, 93 Va. L. Rev. 1899 (2007) (challenging judicial efforts to discern and rely upon private customs in IP cases).

61 Chally, supra note _, at 1271. 
courts actually took ethics into account in rendering their trade secret decisions. ${ }^{62}$

\section{E. Bone's Challenge: Does Trade Secret Law Serve a Purpose?}

Finally, Robert Bone has surveyed this doctrinal morass and decided that the game isn't worth the candle. Bone's argument is that none of the theories of trade secret law work. He claims:

Those who tout economic efficiency either ignore the broader legal context within which trade secret law operates or fail to take into account all the costs of a trade secret system. Those who argue from rights and fairness are unable to identify a right or a coherent conception of fairness that fits trade secret law. And those who point to conventional norms--so-called "generally accepted standards of commercial morality and reasonable conduct"--do so without citing empirical support for the conventions they invoke and without explaining why trade secret remedies are needed to enforce these norms. ${ }^{63}$

He argues that most of the positive virtues of trade secret law can be found in other legal doctrines, notably contract and tort law. ${ }^{64}$ To the extent that trade secret law goes beyond those doctrines, as in the Christopher case, he argues that it is unjustified. ${ }^{65}$ The common law, says Bone, can do just fine - and accomplish most of the same ends - without a doctrine of trade secret law. ${ }^{66}$

62 Don Wiesner \& Anita Cava, Stealing Trade Secrets Ethically, 47 Md. L. Rev. 1076, 1127-28 (1988).

63 Bone, supra note _, at 246.

64 Id. Compare James H.A. Pooley, Restrictive Employee Covenants in California, 4 Santa Clara Comp. \& High Tech. L.J. 251, 282 (1988) (arguing for an understanding of trade secret law that combines property theory and tort theory).

65 Id.

${ }^{66}$ Bone's criticism receives support from a surprising source - Landes and Posner, who assert 
Bone's criticism has particular bite for those who claim that trade secret law doesn't really have a single theoretical basis, but a multitude of them: that it is part tort, part contract, part property, part commercial morality. ${ }^{67}$ Perhaps this is fair enough as a descriptive matter, ${ }^{68}$ but it begs Bone's question: if trade secret law is simply a compilation of bits and pieces of other laws, what good is it to speak of trade secret law at all, and how can one justify the parts of that law that don't track their common-law sources?

In Part III, I suggest that trade secrets are best conceived as IP rights, and that, as IP rights, they work - they serve the basic purposes of IP laws.

\section{Constructing an IP Theory of Trade Secrets}

Trade secrets are best understood, not as applications or extensions of existing common law principles (warranted or unwarranted), but as IP rights. In this section, I explain the two critical features trade secrets share with other IP rights - they promote inventive activity and disclosure of those inventions. I then seek to explain the most significant anomaly - the requirement of secrecy.

\section{A. Incentives to Invent}

that "there is no law of trade secrets." William M. Landes \& Richard A. Posner, The Economic Structure of Intellectual Property Law 355 (2003). See also Edwin C. Hettinger, Justifying Intellectual Property, 18 Phil. \& Pub. Aff. 31, 49 (1989).

67 See Milgrim, supra note _, at (taking this approach); I. Neel Chatterjee, Should Trade Secret Appropriation Be Criminalized?, 19 Hastings Comm./Ent. L.J. 853, 874-75 (1997) (same). One might also read Chiappetta's fragmented theory of trade secret justifications, while styled as a response to Bone, as more of a concession that Bone is at base correct, for Chiappetta believes there is no one justification for trade secret law. Cf. Chiappetta, supra note _, at 73, 75 (noting this objection, but not ultimately resolving it).

68 See ConFold Pacific, Inc. v. Polaris Indus., 433 F.3d 952 (7th Cir. 2006) 
Whatever their theoretical basis, trade secret laws confer an exclusive right on the possessor of valuable information not generally known to or readily ascertainable by competitors. ${ }^{69}$ This is the hallmark of an IP right. Both patents and copyrights confer similar rights to prevent use by others on the developers of new and valuable information. In so doing, it is generally acknowledged that patents and copyrights serve a utilitarian purpose - the grant of that legal control encourages the development of new and valuable information by offering the prospect of supracompetitive returns, returns possible only if the developer does not face competition by others who use the same idea. In so doing, patents and copyrights avoid the risk of underinvestment inherent with public goods, which are more costly to invent than to imitate once invented. $^{70}$

Trade secrecy has the same effect. It gives the developer of new and valuable information the right to restrict others from using it, and therefore the prospect of deriving supracompetitive profits from the information. ${ }^{71}$ This may be true of business as well as technical secrets, since some protection for business ideas helps insure a first mover advantage for those who take risks on untested business models. ${ }^{72}$ True, the right of exclusion in trade secret law is not absolute. The trade secret owner cannot sue someone who develops the idea

69 Uniform Trade Secrets Act sec. 1(4), 14 U.L.A. 433 (1985).

70 See Mark A. Lemley, The Economics of Improvement in Intellectual Property Law, 75 Tex. L. Rev. 989, 993-1000 (1997) and sources cited therein for discussion of this basic proposition. 71 Chally, supra note _, at 1270-71. Compare Risch, supra note _, at 26 (contending that "creating incentive to innovate is a very minor justification of trade secret law.").

72 David Friedman, Trade Secret, in The New Palgrave Dictionary of Law and Economics (1997?). Cf. Michael Abramowicz \& John F. Duffy, Intellectual Property for Market Experimentation, 83 N.Y.U. L. Rev. 337 (2008) (making the case for IP protection for new business ideas). I think their thought experiment goes rather too far - there is a difference between protecting secrets from prying eyes and giving an exclusive franchise to a new market but the incentive point has merit. 
independently, or who reverse engineers a product on the open market to learn the secret. ${ }^{73}$ But the same is true of copyright law. ${ }^{74}$ A right to exclude does not have to be absolute to be effective in rewarding and therefore encouraging innovation. It need merely provide sufficient advantage in terms of lead time or relative costs to minimize or eliminate the public goods problem.

The Supreme Court has acknowledged that trade secrets give companies incentives to innovate. In Kewanee Oil v. Bicron, ${ }^{75}$ the Court refused to hold that patent law preempted trade secret law, reasoning in part that "the patent policy of encouraging invention is not disturbed by the existence of another form of incentive to invention. In this respect the two systems are not and never would be in conflict... Trade secret law will encourage invention in areas where patent law does not reach, and will prompt the independent innovator to proceed with the discovery and exploitation of his invention. Competition is fostered and the public is not deprived of the use of valuable, if not quite patentable, invention."

The additional incentive provided by trade secret law is important for innovation. ${ }^{77}$ Trade secret law reaches into a number of corners patent law cannot. The definition of trade

73 See Restatement of Torts sec. 757, cmt. $f$ at 10 (1939); Restatement (Third) of Unfair Competition sec. 43 (defining improper means of acquiring a trade secret and listing proper means that do not give rise to liability).

74 See, e.g., Merges et al., supra note _, at 389 ("The independent development of a similar or even identical work is perfectly legal" under copyright law); Sega Ents. v. Accolade Inc., 977 F.2d $1510\left(9^{\text {th }}\right.$ Cir. 1992) (reverse engineering for interoperability is protected fair use under copyright).

75416 U.S. 470 (1974).

76 Id. at 481-85. Contra Winston Res. Corp. v. 3M Corp., 350 F.2d 134 (9 $9^{\text {th }}$ Cir. 1965) ("state law protecting trade secrets cannot be based on a policy of rewarding or encouraging the development of secret processes or devices.").

77 Compare Chiappetta, supra note _, at 74 (referring to incentives to invent as "solely a byproduct" of his theory of moral behavior). I believe Chiappetta has the tail wagging the dog here. 
secret (valuable information) is broader than the definition of patentable subject matter, for example, protecting business plans, customer lists, and so-called "negative know-how" against use by others. Patent law cannot protect valuable information of that sort. ${ }^{78}$ Further, inventors must apply for patents, publish their applications after eighteen months, and then wait perhaps four years for the Patent and Trademark Office to decide whether to grant protection. ${ }^{79}$ That significant delay renders patents unavailable as a practical matter in fast-moving industries. Trade secrets, by contrast, are automatically protected upon creation provided the requirements of the statute are met. Finally, patent litigation is as much as three times as expensive as trade secret litigation, with a price tag - a median of $\$ 5$ million per side in legal fees for large cases that puts it out of reach of many small firms. ${ }^{80}$ Small wonder, then, that economic literature suggests that some firms, particularly start-ups, rely heavily on the incentive to invent provided by trade secret law. ${ }^{81}$ In many cases patents are simply not an adequate substitute.

Trade secret law also reaches where contract alone cannot. Trade secret law precludes acquisition of information by strangers using improper means - computer hacking and other

78 While patent law has expanded in recent years to cover new and nonobvious business methods, see State Street Bank \& Trust Co. v. Signature Fin. Group, 149 F.3d 1368 (Fed. Cir. 1998), it does not reach information not embodied in some technical form, such as a customer list. Cf. In re Comiskey, 499 F.3d 1365 (Fed. Cir. 2007).

79 It took patents 2.77 years to issue in the late 1990s, see John R. Allison \& Mark A. Lemley, Who's Patenting What? An Empirical Exploration of Patent Prosecution, 53 Vand. L. Rev. 2099 (2000), but the backlog has increased significantly since that time.

80 American Intell. Prop. L. Ass'n, Report of the Economic Survey 2007 25-26 (2007) (highend patent litigation costs a median of $\$ 3$ million per side through discovery, and $\$ 5$ million per side if it goes to trial; high-end trade secret cases, by contrast, cost a median of \$1 million through discovery and $\$ 1.75$ million through trial).

81 See, e.g., Josh O. Lerner, The Importance of Trade Secrecy: Evidence from Civil Litigation, available at http://papers.ssrn.com/sol3/papers.cfm?abstract_id=6089 (last visited Aug. 21, 2005) (documenting the significance of trade secrets to small firms). For a contrary view, pointing to the benefits to start-ups of using information from others, see Alan Hyde, Working in Silicon Valley: Economic and Legal Analysis of a High-Velocity Labor Market (2003). 
forms of corporate espionage. Further, it extends the reach of the law beyond privity of contract to anyone who comes into contact with a secret knowing that they have acquired it by accident, mistake, or by another's malfeasance. ${ }^{82}$

\section{B. Incentives to Disclose}

Patent and copyright law do not exist solely to encourage invention, however. A second purpose - some argue the main one ${ }^{83}$ is to ensure that the public receives the benefit of those inventions. Patent and copyright law address this goal in various ways. Patent law requires that an applicant describe her invention in sufficient detail that a person of ordinary skill in the field can make and use it, ${ }^{84}$ and requires that that information be published. ${ }^{85}$ As a result, the public is free to read the patent and use the invention once the patent expires twenty years after it is filed, and even before that time scientists can learn from the patent disclosure and use that information to improve on the invention or to design around it. ${ }^{86}$ Further, patent law discourages secrecy in a

82 UTSA $\S 1(\mathrm{~b})(1), 1(\mathrm{~b})(2)(\mathrm{B})(\mathrm{iii}), 1(\mathrm{~b})(2)(\mathrm{C})$.

83 See, e.g., Robert A. Kreiss, Accessibility and Commercialization in Copyright Theory, 43 UCLA L. Rev. 1 (1995); Stewart E. Sterk, Rhetoric and Reality in Copyright Law, 94 Mich. L. Rev. 1197 (1996).

8435 U.S.C. sec. 112, para 1.

85 Id. sec. 122.

86 See, e.g., Matthew J. Conigliaro et al., Foreseeability in Patent Law, 16 Berkeley Tech. L.J. 1045 (2001), On the social benefits of design-arounds that can result from disclosure, see, for example, Warner-Jenkinson Co. v. Hilton Davis Chem. Co., 520 U.S. 17, 36 (1997) (contrasting "the intentional copyist making minor changes to lower the risk of legal action" with "the incremental innovator designing around the claims, yet seeking to capture as much as is permissible of the patented advance"); see also Slimfold Mfg. Co. v. Kinkead Indus., Inc., 932 F.2d 1453, 1457 (Fed. Cir. 1991) (Rich, J.) ("Designing around patents is, in fact, one of the ways in which the patent system works to the advantage of the public in promoting progress in the useful arts, its constitutional purpose."); State Indus. v. A.O. Smith Corp., 751 F.2d 1226, 1236 (Fed. Cir. 1985) ("One of the benefits of a patent system is its so-called 'negative incentive' to 'design around' a competitor's products, even when they are patented, thus bringing a steady flow of innovations to the marketplace."); Craig Allen Nard, A Theory of Claim 
number of ways. ${ }^{87}$ It is not clear that patent law serves this disclosure function particularly well, ${ }^{88}$ but it seems quite clear that dissemination, not just invention, of new information is one of the goals of the patent system. Copyright similarly encourages disclosure in various ways,

Interpretation, 14 HARV. J.L. \& TECH. 1, 40-41 (2000) (“The practice of designing-around extant patents creates viable substitutes and advances, resulting in competition among patented technologies. The public clearly benefits from such activity.") (citations omitted).

87 Section 102(b) requires prompt filing once an inventor begins using an invention in its business, at the risk of losing the right to protection. 35 U.S.C. sec. 102(b). And section 102(g) provides that those who "suppress" or "conceal" an invention lose their claim to be the first inventor, at least until they start down the path to public disclosure. Id. sec. 102(g); Paulik v. Rizkalla, 760 F.2d 1270 (Fed. Cir. 1985) (en banc). As a result, patent law discourages reliance on secrecy, to the point that a first inventor who maintains that invention as a trade secret may not only lose the right to claim patent protection, but may even be sued for patent infringement by a second inventor who did disclose the invention. See, e.g., Gillman v. Stern, 114 F.2d 28, 30 (2d Cir. 1940); Mark A. Lemley et al., Software and Internet Law 193-95 (3d ed. 2006); $c f$. E.I. du Pont de Nemours \& Co. v. Phillips Petroleum Co., 849 F.2d 1430 (Fed. Cir. 1988) (secret research doesn't necessarily lead to a finding of concealment).

${ }^{88}$ Many companies discourage their engineers from reading patents. See, e.g., Edwin H. Taylor \& Glenn E. Von Tersch, A Proposal to Shore Up the Foundations of Patent Law that the Underwater Line Eroded, 20 HASTINGS Comm. \& ENT. L.J. 721, 737 (1998) (“As matters now stand many companies discourage employees from reading patents. This presumably lessens the chance that the company will be found to have knowledge of a patent. However, this defeats the basic purpose of the patents [sic] laws, dissemination of information."); Dennis Fernandez, Move Over Letterman: Top 10 Most Common IP Management Mistakes for New Companies, PAT. STRATEGY \& MGMT., July 1, 2003, at 3 ("Additionally, in many cases it may be appropriate for companies, as a matter of policy, to discourage looking at issued patents owned by other entities so as to avoid awareness of potentially infringed patents."); Mark A. Lemley \& Ragesh K. Tangri, Ending Patent Law's Willfulness Game, 18 Berkeley Tech. L.J. 1085 (2003). While recent changes to the law have reduced the incentive to hide one's head in the sand, see In re Seagate Technology Corp., 497 F.3d 1360 (Fed. Cir. 2007) (en banc), they have not eliminated it.

Further, many don't do a patent search before launching a product. Iain M. Cockburn \& Rebecca Henderson, The 2003 Intellectual Property Owners Association Survey on Strategic Management of Intellectual Property F6 (working paper 2004) (a survey of IP managers found that $67 \%$ disagreed with the statement "we always do a patent search before initiating any R\&D or product development effort."). Even when they do, the quality of the information actually disclosed in a patent may not be particularly helpful to scientists. See Jeanne C. Fromer, Invigorating the Disclosure Function of the Patent System, http://papers.ssrn.com/sol3/papers.cfm?abstract id $=967560$ (working paper 2007) (arguing that patents are not written in ways that communicate useful information to engineers). For an overview of these problems, see Benjamin Roin, Note, The Disclosure Function of the Patent 
originally by conditioning protection on publication of a work ${ }^{89}$ and even today by requiring deposit of the work with the Library of Congress, where it is available to others in most circumstances. ${ }^{90}$ There is decent evidence to support the idea that at least one function of an IP right is not just to encourage new invention, but to encourage the dissemination of those new ideas.

At first blush, trade secret law seems to push in the opposite direction. After all, protection under trade secret laws is conditioned on secrecy, and so it seems to encourage secrecy, or at least the development of inventions that can be kept secret. ${ }^{91}$ Paradoxically, however, trade secret law actually encourages broader disclosure and use of information, not secrecy. It does so in two ways. First, the legal protection trade secret law provides serves as a substitute for investments in physical secrecy that companies might otherwise make. ${ }^{92}$ The facts of $d u$ Pont v. Christopher ${ }^{93}$ once again provide an example. There, the plaintiff was constructing a chemical plant, and during construction it was apparently possible to see the layout of the plant from the air and so to discern the secret process du Pont was using. The court noted that du Pont could have built a temporary roof over the plant during construction, but only at "enormous expense." It didn't need to build that roof because the law protected its interest in avoiding (aerial) prying eyes. Had the law not done so, however, it is reasonable to suppose that du Pont

System (or Lack Thereof), 118 Harv. L. Rev. 2007 (2005).

89 See, e.g., American Visuals Corp. v. Holland, 239 F.2d 740, 744 (2d Cir. 1956) (discussing requirement of publication under the 1909 Act).

9017 U.S.C. sec. 408.

91 See, e.g., Simpson, supra note _ , at 1144-45 (making this argument); Risch, supra note at 38 (noting this objection).

92 See Friedman et al., supra note _ ; Friedman, supra note _ (both making a version of this argument).

93 E.I. DuPont deNemours \& Co. v. Christopher, 431 F.2d 1012 (5 ${ }^{\text {th }}$ Cir. 1970). 
might have built the roof rather than risk loss of its trade secrets. That investment in secrecy would have been inefficient; it is cheaper (both for du Pont and for society) for the law to provide that protection. $^{94}$

There is empirical evidence that over-investment in secrecy is a real problem in the absence of trade secret protection. Examples can be found as far back as the guild system that pervaded Western economies in the middle ages. Guilds were places that could and did develop technical knowledge, but in the absence of legal means to protect that knowledge they went to great lengths to prevent others from learning of it, imposing draconian limits on the mobility of employees and the development of competing firms. ${ }^{95}$ The same problem remains today in countries that do not provide legal protection for secrets. Robert Sherwood studied business practices in Mexico and Brazil, two countries that do not have strong legal protection for trade secrets, and in which resort to the courts may not be viable for a variety of reasons. ${ }^{96}$ He found that companies in those countries make business decisions that inefficiently limit the disclosure of information because they fear that they cannot rely on the courts to prevent the use of information they do disclose. ${ }^{97}$ For example, they may be less willing to contract production out to third parties if it means giving out information about secret processes, even where the third party could use the process more efficiently. They may take elaborate security measures,

94 Landes \& Posner, supra note _ , at 369 ("A decision in favor of Christopher would have induced firms in DuPont's position to invest heavily in roofing their construction sites."). Cf. Edmund G. Kitch, The Law and Economics of Rights in Valuable Information, 9 J. Legal Stud. 683, 696-97 (1980) (reading Christopher as motivated by the desire to prevent "wasteful expenditures," albeit not necessarily by the desire to prevent excessive secrecy).

95 See, e.g., Carlo M. Cipolla, Before the Industrial Revolution: European Economy and Society 1000-1700 261 (2d ed. 1980) (arguing that guilds restricted competition and therefore technological progress in their effort to keep secrets).

96 Robert M. Sherwood, Intellectual Property and Economic Development (1990).

97 Id. at 113 . 
building walls and fences and hiring armed guards. And they may hire employees who they expect to be loyal - such as family members - rather than strangers who would do a better job. ${ }^{98}$

The problem also remains for products or industries that do not qualify for IP protection. Michael Pollan explains that the developers of new breakfast cereals, for example, engage in enormous efforts to protect the secrecy of their new ideas in order to gain a few months firstmover advantage. For the same reason, they operate their own machine shop to design the cereals, rather than outsourcing that work to those presumably more specialized in it. ${ }^{99}$

In short, without legal protection, companies in certain industries would invest too much in keeping secrets. These investments are inefficient, in several senses. In many cases, the problem they address could be avoided by the courts at lower cost than the building of walls and fences. Second, physical investments must be made for each secret, while legal investments need be made only if there is misappropriation. That means that even if a physical investment in secrecy is individually cheap, in the aggregate the cost of having to make that investment for every secret may outweigh the cost of resort to law, which will be necessary only in those few cases in which the secret is actually misappropriated. ${ }^{100}$ Finally, and most important, restrictions on the flow of information between business partners or to new employees slow the process of commercialization and improvement of the secret inventions, and therefore interfere with both

98 Similarly, Michael Risch recounts the story of a client in China that invested extraordinary amounts to protect its secrets, installing fingerprint scanners, limiting Internet access, and filtering outgoing email. Risch, supra note _, at 44.

99 Michael Pollan, The Omnivore's Dilemma 92 (2006) (quoting one cereal company executive as saying: "Recipes are not intellectual property; you can't patent a new cereal. All you can hope for is to have the market to yourself for a few months to establish your brand before a competitor knocks off the product. So we're very careful not to show our hand."). 100 The reverse can sometimes be true, however. If a single fence can protect a host of secrets that the owner would have to sue individually to protect in court, fencing might be cheaper than legal protection. But when secrets are released to third parties - as most of the good ones generally must be - that becomes less likely. 
the invention and disclosure functions of IP law. Trade secret law develops as a substitute for the physical and contractual restrictions those companies would otherwise impose in an effort to prevent a competitor from acquiring their information. In so doing, it encourages disclosure of information that companies might otherwise be reluctant to share for fear of losing the competitive advantage it provides. ${ }^{101}$

Trade secret laws can encourage disclosure in a second way as well: they serve as a partial solution to Arrow's Information Paradox. ${ }^{102}$ The paradox is this: In the absence of any legal protection, the developer of a potentially valuable but secret idea will have a difficult time selling that idea to someone who could make more efficient use of it, because in order to sell the idea he will have to disclose it to allow the buyer to evaluate it, but disclosing it destroys the value inherent in its secrecy. To see this, imagine that I tell you I have a great idea, and I'll share it with you for $\$ 1$ million. Should you take the deal? You can't know the answer to that question unless I tell you what the idea is. But in the absence of legal protection, if I tell you what my idea is, you no longer need to pay me $\$ 1$ million.

101 See also Risch, supra note _, at 42-43.

Economists sometimes suggest that a benefit of patents over secrets is that the disclosure of inventions in a patent communicates information to competitors and therefore avoids wasteful duplication of research and development. See, e.g., Nancy T. Gallini, Patent Policy and Costly Imitation, 23 RAND J. Econ. 52 (1992). I don't find this argument persuasive, however, both because I think parallel research by independent companies can often be valuable, see Mark A. Lemley, The Economics of Improvement in Intellectual Property Law, 75 Tex. L. Rev. 989 (1997), and because all available evidence suggests that patents do not in fact serve much of a disclosure function. See, e.g., Mark A. Lemley, Ignoring Patents, 2008 Mich. St. L. Rev. 1; Benjamin Roin, The Disclosure Function of the Patent System (or Lack Thereof), 118 Harv. L. Rev. 2007 (2005).

102 Kenneth J. Arrow, Economic Welfare and the Allocation of Resources for Invention, in The Rate and Direction of Inventive Activity 609, 615 (Richard R. Nelson ed., 1962) (arguing that sellers will not disclose information to buyers absent legal protection, and so buyers will be unable to value that information). 
Now add trade secret law (or any IP right) to the picture. ${ }^{103}$ The existence of a legal right to prevent others from using or disclosing my idea in breach of a confidential relationship allows me to disclose the idea in pre-contractual negotiations, secure in the knowledge that the other side isn't free to take the idea without compensating me. ${ }^{104}$ The law, by giving certain rights to the holder of the secret, allows him to disclose information he would otherwise have been unwilling to share, and therefore permits business negotiations that can lead to commercialization of the invention or sale of the idea, serving both the disclosure and incentive functions of IP law. ${ }^{105}$ True, the parties could have entered into a contract limiting what could be done with the information, but the putative buyer may be reluctant to sign such a contract without knowing what they might be limiting themselves from using. ${ }^{106}$ Both venture capitalists and Hollywood executives, for example, are notoriously unwilling to sign nondisclosure agreements before reading business plans or movie scripts. ${ }^{107}$ Trade secret law reaches beyond

103 There is substantial literature on patents (as opposed to trade secrets) as a way out of Arrow's paradox. See, e.g., Paul J. Heald, Transactions Costs and Patent Reform, 23 Santa Clara Comp. \& High Tech. L.J. 447, 454 (2007); James J. Anton \& Dennis A. Yao, Expropriaton and Inventions: Appropriable Rents in the Absence of Property Rights, 1 Am. Econ. Rev. 190, 191-92 (1994); Robert P. Merges, Intellectual Property and the Costs of Commercial Exchange, 93 Mich. L. Rev. 1570, 1590 (1995).

104 Cf. E. Allen Farnsworth, Precontractual Liability and Preliminary Agreements: Fair Dealing and Failed Negotiations, 87 Colum. L. Rev. 217 (1987) (discussing efforts to avoid Arrow's paradox by entering into "agreements to agree" and the like).

105 Thus, Simpson has it backwards to suggest that trade secret law will discourage cooperation between companies. Simpson, supra note _, at 1154-55. It will encourage such cooperation far more than the absence of protection.

106 One way around this is to sign a contract that agrees to keep the information secret only if it is in fact a trade secret, and to allow the use of public domain information or information already in the buyer's possession. But writing a contract like this merely attempts to recreate between the parties what trade secret law already provides.

107 See, e.g., Deborah J. Ludewig, Optimizing the Benefits of Term Sheets and Ancillary Agreements, 1642 PLI/Corp 43 (2008) ("As practitioners in Silicon Valley are aware, venture capital firms will not execute any form of nondisclosure agreement, except in very rare and unusual circumstances, even though they require prospective investment targets to provide 
contract law by allowing courts to infer the existence of a confidential relationship from circumstances in which transactions might be difficult or impossible without that assumption. ${ }^{108}$

The fact that trade secret law reduces rather than increases an innovative firm's investment in secrecy answers many of the objections people have offered to trade secret law, in particular Bone's claim that legally-induced secrecy will interfere with rather than promote innovation. ${ }^{109}$ Bone's argument is right as far as it goes - companies that keep too much secret may reduce rather than increase aggregate innovation - but for the reasons I outline in this section, that argument is a justification for, not a challenge to, trade secret law.

\section{Channeling Protection Between Patents and Trade Secrets}

So far, so good. But at this point the reader might object that, if the goal of trade secret law is to give legal rights over an invention while encouraging its disclosure, we don't really need the secrecy requirement at all. In this vein, a number of scholars have suggested that any investment in protecting trade secrecy is wasted, since the law is requiring companies to spend money in ways that reduce, not increase, the dissemination of ideas. ${ }^{110}$ If the goal of trade secret

extensive confidential information before a funding event."); but cf. Arthur R. Miller, Common Law Protection for Products of the Mind: An "Idea" Whose Time Has Come, 119 Harv. L. Rev. 703, 714 (2006) (asserting without support that this was untrue for a brief period in the 1990s).

108 This was the case in Smith v. Dravo Corp., 203 F.2d 369 ( $7^{\text {th }}$ Cir. 1953), for instance, in which the court implied a confidential relationship between parties negotiating over the sale of a business, despite the fact that the parties did not sign a nondisclosure agreement. See also Phillips v. Frey, 20 F.3d 623, 631-32 (5 ${ }^{\text {th }}$ Cir. 1994) (same).

109

Bone, supra note _, at 264-72.

110 Kitch, supra note _, at 698 (suggesting that it makes no sense to require proof of efforts to protect secrets, except perhaps as evidence of the existence of a secret). Cf. Friedman et al., supra note _, at 67 (arguing that trade secret protection should be available if, but only if, the costs of legal enforcement are less than the costs of secrecy). Friedman, Landes and Posner are correct only if the social as well as the private costs of secrecy are taken into account.

One might also include as a variant of this point Bone's argument that we don't need 
law is to encourage dissemination by giving the security of a legal right, this argument runs, why not just grant that right to any information, regardless of whether it is secret?

The problem with this argument is that without some basis for defining the legal right, it will sweep too broadly. If I can get ownership rights in any information, no matter how public, the result will be to deter, not promote, the dissemination of that information. If any idea, no matter how public, is subject to a claim of legal rights, individuals and companies will reasonably worry about using any information they don't themselves develop. If I could sue you for repeating my explanation for trade secret law, the result is not likely to be wide discussion of that explanation, even if I have no intention of suing you for discussing my idea. ${ }^{111}$ And while we could theoretically substitute a defendant's conduct for proof of secrecy as the basis for entitlement to a legal right, as we saw in Part II such conduct-based definitions are circular and ultimately empty.

Granted that we need some definition of the entitlement, why secrecy? The answer, I believe, is that the secrecy requirement serves to channel inventors into the appropriate form of IP protection. Consider three different types of inventions: one that is impossible to conceal once it is in widespread use (think of the wheel or the paper clip), one that is impossible to discern by evaluating the product (think of the formula for Coca-Cola), and one that can be discerned by evaluating the product, but only with difficulty (think of software source code, which is not evident from the object code sold to customers but which might be reverseengineered). In a world with patent law but no trade secret law, companies with inventions in the first category - those who have developed what I will call inherently self-disclosing

trade secret law because existing legal doctrines of contract, tort and property already serve those purposes. See Bone, supra note , at 245-46.

111 I don't. 
inventions - will turn to patent law if they can. If not, they will be out of luck. If the paper clip weren't patentable, ${ }^{112}$ companies wouldn't be able to keep it secret and still make much profit from it. Their best option would likely to be to sell the paper clip and hope to make some profit from brand recognition or first mover advantages.

Companies with inventions in the second category, by contrast - those who develop inventions that are not transparent to the world, such as chemical processes and some formulas might well decide to keep an invention secret in the absence of legal protection, ${ }^{113}$ reasoning that they may get a greater advantage from secrecy than from patent law, since patents may be held invalid, may be easy to design around, ${ }^{114}$ and in any event will expire within twenty years. Indeed, there is some empirical evidence that they do so - that where secrecy is possible, inventors choose it over patent protection. ${ }^{115}$ Without trade secret law, the efforts those companies take to protect their secrets may be excessive, as I discussed in the previous section.

112 It was. Indeed, there were many different claimed inventors and even substantial litigation over ownership of the exclusive rights to the paper clip. See, e.g., Cushman Denison Mfg. Co. v. Denny, 147 F. 734, 734-35 (S.D.N.Y. 1906). And more modern variants are still patented today. See U.S. Patent No. 5,179,765 (issued Jan. 19, 1993) ("Plastic Paper Clip").

113 See Risch, supra note _, at 38 (arguing that the possibility that companies will keep information secret anyway means that the marginal social cost of legal protection for withholding information from the public is "minimal"). As I discuss in the text, I think Risch is right, but does not take this point far enough - it's not just that the possibility of secrecy without protection reduces the social cost of trade secret law; eliminating that possibility is an affirmative social benefit of the law.

114 See Paul M. Janicke \& LiLan Ren, Who Wins Patent Infringement Cases?, 34 AIPLA Q.J. 1 (2006) (finding that patent owners win only about $25 \%$ of infringement suits). The doctrine of equivalents exists to deal with the problem of patent claims that are too easy to evade, but its impact on modern patent law is relatively minimal. See John R. Allison \& Mark A. Lemley, The (Unnoticed) Demise of the Doctrine of Equivalents, 59 Stan. L. Rev. 955 (2007) (documenting the small number of cases in which the patentee wins a doctrine of equivalents argument).

115 See Petra Moser, Why Don't Inventors Patent?, NBER working paper (Nov. 12, 2007). Moser studies over 7000 inventions in the US and Britain between 1851 and 1915. She finds that as reverse engineering an invention becomes more feasible, inventors are more likely to turn from secrecy to patent protection. 
That overinvestment may be specific - protection of a particular idea - or general - imposing too many restrictions on employees and business partners. Either way, the result is both inefficiency - overinvestment in secrecy - and that the benefits of public disclosure of information are lost. ${ }^{116}$

A secrecy requirement provides protection to companies in the second category, not in the first. Thus, it ensures that trade secret law provides legal protection in circumstances in which inventors might otherwise choose excessive secrecy, but denies protection to inventions that companies would not keep secret in the absence of patent protection. By drawing this line, even the secrecy requirement of trade secret law has the surprising effect of reducing, not increasing, the secrecy of inventions. ${ }^{117}$

What, then, of inventions in the intermediate category? Companies with inventions in this third category might or might not rely on secrecy rather than patent law. ${ }^{118}$ Both approaches have risks. As noted above, patents might be invalid, or easy to evade, and in any event will expire in a set period of time. On the other hand, reliance on secrecy provides only tenuous protection, since the secret could be discerned by reverse engineering or independent development or disclosed by an employee or business partner in the absence of trade secret law.

116 The same can be said - with some adaptations - of business rather than technical trade secrets. Consider customer information, some of which is readily accessible to the public (phone numbers) and some of which is not (purchasing budget for each customer, likes and dislikes, etc.). In a world without trade secret protection, companies might put too much effort into protecting the latter category of information from disclosure. Unlike technical information disclosed in products, these efforts are likely to take the form of compartmentalization of information within the company or of efforts to prevent salespeople from leaving the company through noncompetition agreements and the like. Trade secret law may substitute for some of those efforts, as it does in California, which forbids restrictions on employee mobility, see Cal. Bus. \& Prof. Code $\S 16600$, but allows enforcement of claims to information that is in fact secret.

117 See also Risch, supra note _, at 43.

118 While the example I use here involves computer source code, for simplicity's sake I ignore the fact that software is subject to both patent and copyright protection. 
In this case, the effects of introducing trade secret law are ambiguous. If companies in this third category would have opted for secrecy, then the introduction of trade secret law reduces the negative effects of that secrecy for the same reasons it did in the second category. But if they would have opted for patent protection rather than secrecy without law, adding trade secret law might encourage them to keep secret information they would otherwise have patented (and therefore disclosed). To avoid inadvertently encouraging secrecy rather than disclosure, trade secret law incorporates limits on the scope of the right, notably the defenses of independent development and reverse engineering. As the Supreme Court suggested in Kewanee, and as commentators have suggested, these defenses weaken the trade secret right sufficiently that it does not entice inventors to choose secrecy over patent protection. ${ }^{119}$ Taken together, the secrecy requirement and the relative weakness of the trade secret law help ensure that the law protects those who would otherwise rely on secrecy without law, and encourages disclosure in those cases, while not displacing patent law as the means of protection for self-disclosing inventions. Put another way, the secrecy requirement channels particular inventors to the form of IP protection that best achieves the goals of society.

Trade secret law may or may not get this judgment right. The enforcement of trade secrets has costs as well as benefits, ${ }^{120}$ and as with all IP rights, it is hard to know whether we are getting the balance right. ${ }^{121}$ But the theory of trade secrets as IP rights coheres, both in the sense that trade secrets fit quite nicely within the goals and framework of IP law more generally and

119 See, e.g., Kewanee Oil Co. v. Bicron Corp., 416 U.S. 470, 481-485 (1974); Paul Goldstein, Kewanee Oil Co. v. Bicron Corp.: Notes on a Closing Circle, 1974 S. Ct. Rev. 81.

120 See Bone, supra note _, at 272-81 (detailing those costs).

121 See Chiappetta, supra note _, at 88. For a more general discussion of this problem, see Lemley, Free Riding, supra note _, at _; David McGowan, Copyright Nonconsequentialism, 69 Mo. L. Rev. 1 (2004). 
that the same arguments and concerns that arise in other areas of IP arise in trade secret law. Resolving those arguments, and striking that balance, is the subject of Part IV.

\section{Implications for Trade Secret Law}

How does this understanding of trade secret law translate into policy? As a preliminary matter, the articulation of a solid theoretical basis for trade secret law helps defuse Robert Bone's criticism of the doctrine. Trade secret laws promote the goals of IP rights more generally, and do so in a way that follows directly from many of the most fundamental rules of trade secret law.

Beyond justifying the entire endeavor, the IP theory of trade secret rights has several implications for the development of trade secret doctrine. In this section, I discuss two primary implications and some other possible lessons theory can provide for practice.

\section{A. The Centrality of Secrecy}

One implication of the theory I articulated in Part III is that the requirement of secrecy is not an accident or a mistake. It is a central part of what makes trade secret law work. A significant benefit of thinking of trade secrets as IP rights rather than as unfair competition torts is that it puts the focus of the legal inquiry first and foremost on whether the plaintiff has an IP right at all. The Uniform Trade Secrets Act, for example, defines the legal rights of trade secret owners by requiring the existence of a secret and defining what constitutes a secret. ${ }^{122}$ Doing so prevents plaintiffs from ignoring or glossing over proof of the existence of a trade secret in their effort to prevent what they see as improper use of their information.

This point may seem obvious - of course winning a trade secret case requires the plaintiff

122 Uniform Trade Secrets Act sec. 1(4), 14 U.L.A. 433 (1985). 
to prove the existence of a trade secret. But in fact a number of cases and commentators that have applied the tort theory of trade secrecy have minimized or even ignored that requirement. ${ }^{123}$ The Supreme Court itself led courts astray in $d u$ Pont v. Masland, where it said that " $[\mathrm{w}]$ hether the plaintiffs have any valuable secret or not, the defendant knows the facts, whatever they are, through a special confidence that he accepted. The property may be denied, but the confidence cannot be." ${ }^{\prime 124}$ A number of courts applying the Restatement of Torts have followed the lead of the Masland dictum, holding that defendants misappropriated trade secrets by acquiring or using a secret by improper means or in breach of a confidential relationship without determining that the information was itself a secret at all. An example is Smith v. Dravo Corp., in which the defendant had clearly made use of information obtained from the plaintiff during acquisition negotiations in later entering the market in competition with the plaintiff. ${ }^{125}$ The court found liability on the basis of the defendant's admittedly troubling business behavior. ${ }^{126}$ But in doing so, the court elided the distinction between the use of information that was truly secret, such as the plaintiff's confidential patent applications, and information that was readily accessible to the public, such as the dimensions of plaintiff's shipping containers that were already on the

123 That their doing so stems from the tort theory of trade secrets is evident from Kamin v. Kuhnau, 374 P.2d 912, 918-19 (Or. 1962), which said "[t]he cases adopting the higher standard of 'commercial morality' emphasize the breach of confidence reposed in the defendant, rather than the existence of the trade secret." See also FMC Corp. v. Varco Int'l, Inc., 677 F.2d 500, $503\left(5^{\text {th }}\right.$ Cir. 1982) ("The fact that a trade secret is of such a nature that it can be discovered by experimentation or other fair and lawful means does not deprive its owner of the right to protection from those who would secure possession of it by unfair means.").

Among commentators arguing against strict application of the secrecy requirement on tort grounds, see William L. O'Brien, Trade Secret Reclamation: An Equitable Approach in a Relative World, 21 J. Marshall J. Comp. \& Info. L. 227 (2003).

124 E.I. du Pont \& Co. v. Masland, 244 U.S. 100, 102 (1917).

125 Smith v. Dravo Corp., 203 F.2d 369 ( $7^{\text {th }}$ Cir. 1953).

126 The defendant rejected the plaintiff's business proposal on January 30 , announced that they would compete the next day, and launched their competing product five days after that. $I d$. at 
market. $^{127}$

There are a number of other examples. In United States Sporting Products v. Johnny Stewart Game Calls, ${ }^{128}$ for example, the court held that publicly sold, uncopyrightable recordings of bird calls were protectable. The court focused on the labor the plaintiff had put into collecting them, but ignored the fact that they were not secret. In Rohm \& Haas Co. v. Adco Chemical Co., ${ }^{129}$ the court ignored the fact that the defendant's alleged secret process was in fact disclosed in a number of industry publications because it found that the defendant did not in fact learn the information from those publications, but instead from the plaintiff. And in Franke v. Wiltschek, the Second Circuit elevated this idea to a general rule based on Masland:

It matters not that the defendants could have gained their knowledge from a study of the expired patent and plaintiff's publicly marketed product. The fact is they did not. Instead, they gained it from plaintiffs via their confidential relationship, and in doing so incurred a duty not to use it to plaintiff's detriment. This duty they have breached. ${ }^{130}$ These courts have departed from the principle of trade secrets as IP rights. Perhaps they are blinded by the defendant's suspicious conduct, or perhaps they view employee mobility itself as suspect. Whatever the reason, they ignore the critical limit on the scope of that IP right. Doing so risks turning trade secrets from a well-defined legal right that serves the broader

127 Indeed, the Pennsylvania Supreme Court later criticized Smith on that basis. Van Prod. Co. v. General Welding \& Fabricating Co., 213 A.2d 769, 779-80 (Pa. 1965). For other cases implying duties of confidence, see 1 Milgrim, supra note _ , §§3.01-3.02.

128865 S.W.2d 214 (Tex. Ct. App. 1993).

129689 F.2d 424 (3d Cir. 1982).

130209 F.2d 493, 495 (2d Cir. 1953). Among other examples, see, e.g., Kamin v. Kuhnau, 374 P.2d 912 (Or. 1962); Note, The "Genetic Message" from the Cornfields of Iowa: Expanding the Law of Trade Secrets, 38 Drake L. Rev. 631 (1989) (describing a similar case involving publicly sold grain). For discussion of this approach, see ,e.g., Sharon K. Sandeen, Relative Privacy: What Privacy Advocates Can Learn From Trade Secret Law, 2006 Mich. St. L. Rev. 667, 696- 
purposes of IP law into a standardless, free-roaming right to sue competitors for business conduct that courts or juries might be persuaded to deem objectionable. Secrecy is critical to ensuring that trade secret law doesn't interfere with robust competition or with the dissemination of new ideas. Courts that ignore that requirement undermine the purpose of trade secret law. ${ }^{131}$ The dictum of Masland should not only be disregarded but reversed: "The starting point in every case of this sort is not whether there was a confidential relationship, but whether, in fact, there was a trade secret to be misappropriated." 132 Understanding trade secrets as IP rights, and therefore as premised first and foremost on the existence of such a legal right, will help restore the centrality of the secrecy inquiry. ${ }^{133}$ And as a corollary, it may help ensure that the plaintiff clearly defines what it claims to own, rather than (as happens all too often in practice) falling back on vague hand-waving. ${ }^{134}$

97, 702 ("trade secret law, prior to the UTSA, arguably overemphasized relationships").

131 Thus, I disagree with Risch, who argues that competitors should be held liable if they acquire information from the plaintiff even though it was readily accessible from public sources. Risch, supra note _, at 54-55. Nor do I think Risch's position is supported by California law; while California modified the UTSA to make "ready ascertainability" of information a defense, there seems little question that that move merely shifted the burden of proof, and did not change the UTSA rule that secrecy, not merely misappropriation, is a required element of the cause of action. See, e.g., Impaxx v. Thompson, 7 Cal. Rptr.3d 427 (Ct. App. 2003); Fortna v. Martin, 323 P.2d 146 (Cal. Ct. App. 1958).

132 Den-Tal-Ez, Inc. v. Siemens Cap. Corp., 566 A.2d 1214, 1228 (Pa. Super. 1989). Accord Patriot Homes v. Forest River Housing, Inc., 512 F.3d 412, 415 ( $7^{\text {th }}$ Cir. 2008).

133 Luigino's, Inc. v. Peterson, 2002 WL 122389 (D. Minn. Jan. 28, 2002) (threshold focus in a trade secret case must be on the existence of "property rights" - that is, on secrecy), aff' $d, 317$ F.3d 909 ( 8 th Cir. 2003); Graves, supra note _, at 47 ("A property conception may help convince a court to require a more detailed identification of the claims and thus give the defense a better opportunity to show that the information is in the public domain. If the court views a trade secret as a property right, that right necessarily must have metes and bounds ...").

134 California is one of the few states to require any specificity in the definition of a trade secret. Cal. Code Civ. Proc. §2019(d) [note - I think this got renumbered]. For an argument for greater specificity, see Julie A. Henderson, The Specifically Defined Trade Secret: An Approach to Protection, 27 Santa Clara L. Rev. 537 (1987). 


\section{B. The Relationship Between Trade Secret Law and Other Torts}

The importance of secrecy in channeling inventors between patent and non-patent IP protection has a second implication as well. Requiring trade secret plaintiffs to prove they own a real secret will do little good if those same plaintiffs can turn to other legal doctrines to provide equivalent protection without the requirement of secrecy. Unfortunately, there a number of state common law doctrines that offer just that prospect. The common law doctrine of breach of confidence, for example, required only proof that something was offered to the defendant in confidence, and that the defendant disclosed that information. ${ }^{135}$ Other common law doctrines, including misappropriation, ${ }^{136}$ unfair competition, ${ }^{137}$ and unjust enrichment (at least in those states in which it is an independent cause of action), ${ }^{138}$ similarly have no elements other than a loose definition of improper conduct. ${ }^{139}$ And still other torts, such as interference with contract or "idea submission," 140 may well overlap almost completely with a trade secret claim in

135 See, e.g., Lehman v. Dow Jones \& Co., 783 F.2d 285, 299 (2d Cir. 1986) (defining the tort as protecting "information that does not qualify as a trade secret if the information is disclosed in confidence and later used in a manner that breaches that confidence."). The idea derives from a comment in the original Restatement of Torts to the effect that "[a]lthough given information is not a trade secret, one who receives the information in confidential relation or discovers it by improper means may be under some duty not to disclose or use the information." Restatement of Torts sec. $757 \mathrm{cmt}$. b. For a discussion of the doctrine and its relationship to trade secret law, see Pooley, supra note , sec. 3.04[4].

136 International News Serv. v. Associated Press, 248 U.S. 215 (1918).

137 See Pooley, supra note _ , sec. 3.04[2] (discussing the tort of unfair competition as a "catchall theoretical rubric").

138 This is true in Colorado, for example. See Univ. of Colorado Found. v. American Cyanamid Co., 342 F.3d 1298 (Fed. Cir. 2003) (recognizing independent cause of action for unjust enrichment in Colorado).

139 Cf. ConFold Pacific, 433 F.3d at 957 (referring to the "bewildering array" of common law claims in the shadow of trade secrecy).

140 On the latter, see, e.g., Nadel v. Play-by-Play Toys \& Novelties, Inc., 208 F.3d 368 (2d Cir. 
particular cases. ${ }^{141}$

Trade secret law should preempt these torts when they are applied to protect information that would, if secret, have been protected by trade secret law. ${ }^{142}$ That is, a plaintiff who complains of the defendant's use of its information, but who cannot prove that information is a secret, should not be able to rely on one of these torts (or any other common law variants) to bypass the requirement that it prove secrecy. ${ }^{143}$ If trade secret law doesn't preempt these torts, the point of the secrecy requirement will be lost, and with it the benefits of dissemination of new inventions. Companies will be unable to rely on the presence of ideas in the public domain; any information might potentially be subject to one of these torts. ${ }^{144}$ As a result, they will be less willing to compete vigorously on the merits. Departing employees will be less willing to rely on information in the public domain to start new companies, and as a result more reluctant at the margins to start those companies. As Jim Pooley notes, "there is arguably little social utility" in

2000); Desny v. Wilder, 46 Cal.2d 715, 299 P.2d 257 (1956); Mary LaFrance, Something Borrowed, Something New: The Changing Role of Novelty in Idea Protection Law, 34 Seton Hall. L. Rev. 485 (2004). For a suggestion that the prior "idea submission" case law has been rolled into modern trade secret law, see Edmund W. Kitch, The Expansion of Trade Secrecy Protection and the Mobility of Management Employees: A New Problem for the Law, 47 S.C. L. Rev. 659, 663 (1996).

141 Compare Convolve, Inc. v. Compaq Computer Corp., 2006 WL 839022 (S.D.N.Y. 2006) (interference claims preempted under California law) with Ethylpharm S.A. France v. Bentley Pharms., Inc., 388 F. Supp. 2d 426 (D. Del. 2005) (interference claim not preempted because it is not necessarily coextensive with trade secret protection).

142 And indeed the UTSA does preempt state torts, with the notable exception of contract law. UTSA § 7; Digital Envoy, Inc. v. Google Inc., 370 F. Supp. 2d 1025 (N.D. Cal. 2005); Auto Channel v. Speedvision, 144 F. Supp. 2 d 784 (W.D. Ky. 2001); R.K. Enterprise v. Pro-Comp Mgmt. Inc., 158 S.W.3d 685 (Ark. 2004); contra PostX Corp. v. Secure Data in Motion, Inc., 2004 WL 2663518 (N.D. Cal. Nov. 20, 2004). For an argument that this must be read to preempt the common law torts described in text, see James H. Pooley, The Uniform Trade Secrets Act: California Civil Code § 3426, 1 Santa Clara Comp. \& High Tech. L.J. 193, 209 (1985).

143 See, e.g., CardioNet, Inc. v. LifeWatch Corp, 2008 WL 567031 (N.D. Ill. Feb. 27, 2008).

144 See ConFold Pacific, Inc. v. Polaris Indus., Inc., 433 F.3d 952, 959 ( $7^{\text {th }}$ Cir. 2006) ("if information is not a trade secret and is not protected by ... a broader intellectual property right . 
allowing state claims based on misappropriation of trade secrets to go forward if the plaintiff cannot prove the elements of a trade secret claim. ${ }^{145}$

Once again, conceiving of trade secrets as IP rights helps achieve the goal of preemption of conflicting common law torts. ${ }^{146}$ If trade secret law is one tort among many common law torts, there is no reason to privilege it over other torts when the two conflict. ${ }^{147}$ But we have a well-established set of principles by which IP rights preempt state common law rules that interfere with those rights. ${ }^{148}$ We have those preemption principles because we recognize IP rights as utilitarian rules created by government to address public goods problems, and the policy decisions implicit in those rules will at a minimum be complicated and may even be overridden

.., anyone is free to use that information without liability.").

145 Pooley, supra note _, sec. 3.04[4], at 3-43 to 44.

This is why I believe Bone has it backwards to suggest that a world without trade secret law, but with common law torts, would give greater freedom to reverse-engineering, independent development, and employee mobility. See Robert G. Bone, Exploring the Boundaries of Competitive Secrecy: An Essay on the Limits of Trade Secret Law, in Law, Information, and Information Technology 99, 121-23 (Eli Lederman \& Ron Shapira eds. 2001). Trade secret law has limits, and can supplant the application of common law torts that lack those limits.

146 Accord Graves, supra note _, at 56.

147 Indeed, some courts applying the tort theory have allowed claims for misappropriation to proceed where trade secret claims failed, even in jurisdictions in which the UTSA seems clearly to foreclose application of those torts. See, e.g., City Solutions, Inc. v. Clear Channel Comms., Inc., 242 F. Supp. 2d 720, 735 (N.D. Cal. 2003), aff'd in relevant part 365 F.3d 835, $842\left(9^{\text {th }}\right.$ Cir. 2004); Imax Corp. v. Cinema Tech., Inc., 152 F.3d 1161, 1169 (9 $9^{\text {th }}$ Cir. 1998); Burbank Grease Servs. v. Sokolowski, 717 N.W.2d 781 (Wis. 2006). But see Mortgage Specialists, Inc. v. Davey, 904 A.2d 652 (N.H. 2006) (rejecting Burbank Grease). For criticism of these cases based on lack of uniformity, see Sarah Gettings, Burbank Grease Servs. v. Sokolowski: Frustrating Uniformity in Trade Secret Law, 22 Berkeley Tech. L.J. 423 (2007).

148 See, e.g., Sears, Roebuck \& Co. v. Stiffel Co., 376 U.S. 225, 229 (1964); Compco Corp. v. Day-Brite Lighting, Inc., 376 U.S. 234 (1964); Bonito Boats, Inc. v. Thunder Craft Boats, Inc., 489 U.S. 141 (1989); Rice, supra note _; John S. Wiley Jr., Bonito Boats: Uninformed But Mandatory Innovation Policy, 1989 S. $\overline{\mathrm{Ct}}$. Rev. 283; Paul Heald, Federal Intellectual Property Law and the Economics of Preemption, 76 Iowa L. Rev. 959 (1991). For a detailed discussion of those rules as applied to trade secret law, see Sharon K. Sandeen, A Contract By Any Other Name is Still a Contract: Examining the Effectiveness of Trade Secret Clauses to Protect 
by layering on additional causes of action not designed with public goods problems in mind.

The Sears and Compco cases provide IP examples of how this can work. ${ }^{149}$ While those cases involved federal Supremacy Clause preemption of state laws, there are state-level examples as well. ${ }^{150}$ Most notably, the California Supreme Court held that California's unfair competition statute could not be applied to undo the limits of the Cartwright Act, the state's antitrust law. ${ }^{151}$ The rationale was the same as it is here - applying a general, open-ended tort to override the specific limits of a statutory policy defeats the purpose of that policy. Treating trade secret law as an IP right dependent on proof of secrecy highlights the policy stakes, and will encourage courts to preempt common law claims that threaten to undermine the balance trade secret law strikes. ${ }^{152}$

Databases, 45 Idea 119 (2005).

149 Sears, 376 U.S. at 229; Compco, 376 U.S. at 234. Doug Lichtman has criticized the preemption of state IP-like rights. Douglas Gary Lichtman, The Economics of Innovation: Protecting Unpatentable Goods, 81 Minn. L. Rev. 693 (1997). But his argument is based on narrowly-tailored state laws that serve only to recoup development costs. Trade secret may fit that model; amorphous notions of misappropriation and unfair competition do not.

150 Cf. Dan L. Burk, Protection of Trade Secrets in Outer Space Activity: A Study in Federal Preemption, 23 Seton Hall L. Rev. 560 (1993) (discussing the possibility of federal preemption of state law in territory where federal law is exclusive).

151 Cel-Tech Comms. v. Los Angeles Cellular Tel. Co., 83 Cal. Rptr. 2d 548 (Cal. 1999) (state antitrust law preempts allegations of unfair competition between competitors unless those allegations are sufficient to state an antitrust claim).

152 See Auto Channel, Inc. v. Speedvision Network, LLC, 144 F. Supp. 2d 784, 790 (W.D. Ky. 2001); Automed Techs., Inc. v. Eller, 160 F. Supp. 2d 915, 921-22 (N.D. Ill. 2001); Frantz v. Johnson, 999 P.2d 351, 358 n.4 (Nev. 2000); AcryMed, Inc. v. ConvaTec, 317 F. Supp. $2 d 1204$ (D. Or. 2004); Pooley, supra note _, sec. 2.03[6]. But see Boeing Co. v. Sierracin Corp., 738 P.2d 665, 673-74 (Wash. 1987) (refusing to preempt breach of confidence claim); Burbank Grease Servs. v. Sokolowski, 717 N.W.2d 781 (Wis. 2006) (refusing to preempt misappropriation claim); Hecny Transportation, Inc. v. Chu, 430 F.3d 402 ( $7^{\text {th }}$ Cir. 2005) (refusing to preempt theft and fraud claims). The UTSA expressly preempts other state claims. UTSA $§ 7$. But common law courts have done so as well. See Sheets v. Yamaha Motors Corp., 849 F.2d 179, 184 ( $5^{\text {th }}$ Cir. 1988) ("Sheets is not entitled to fall back on the equitable doctrine of unjust enrichment after failing to establish a trade secret"); Gary Van Zeeland Talent, Inc. v. Sandas, 267 N.W.2d 242, 249 (1978). 


\section{Other Implications for Trade Secret Doctrine}

Besides the centrality of secrecy to trade secret law, and the attendant need to preempt torts that undermine that requirement, an IP theory of trade secret law may have other implications for trade secret doctrine as well. The implications I discuss in this section are more speculative; they represent, not necessary implications of the IP theory of trade secrets, but legal doctrines that seem to fit uneasily with the IP theory or that are likely to draw greater sustenance for that theory.

\section{Reasonable Efforts to Protect Secrecy}

First, while proof that the plaintiff's information is secret serves a critical role in channeling towards trade secret protection only those inventions that are best served by trade secret law, the same is not necessarily true of the parallel requirement that trade secret owners take reasonable efforts to protect their secrets. ${ }^{153}$ That requirement seems to stem from traditional tort notions of contributory negligence, under which plaintiffs were barred from relief if they themselves contributed to the tort. The explanation I have offered for trade secret law (and for the secrecy requirement) is not one that values secrecy as an end in itself; far from it. The benefit of trade secret law is that it reduces investment in secrecy compared to what would happen absent that law. So there is no reason we should want to establish a minimum investment level as an end in itself. ${ }^{154}$ And it may have negative consequences in particular

153 On that requirement, see UTSA sec. 1(4)(ii); Rockwell Graphic Sys., Inc. v. DEV Indus., 925 F.2d 174 ( $7^{\text {th }}$ Cir. 1991); Electro-Craft Corp. v. Controlled Motion, Inc., 332 N.W.2d 890 (Minn. 1983).

154 Accord Kitch, supra note _, at 698. 
circumstances. $^{155}$

The question then becomes whether reasonable efforts serve some other end. For example, some courts suggest that efforts to protect information as a secret are a sufficiently strong proxy for the secrecy of the invention that we should rely on them as evidence in support of the existence of a secret. ${ }^{156}$ But they are surely not perfect evidence; any litigator will tell you that companies regularly label as secret lots of things that clearly aren't secret. Even assuming that reasonable efforts at secrecy do offer such evidence, that doesn't justify the imposition of reasonable efforts as a separate requirement, just the consideration of that evidence in the overall secrecy inquiry. Alternatively, it may be that efforts to protect secrecy serve to put potential defendants on notice of the claim of secrecy, and therefore prevent inadvertent misappropriation. This may be true of some, but not all, efforts at secrecy, so again, it seems to justify reasonable efforts only as evidence, not as a separate requirement. More to the point, it will be true only as to some defendants; others may be aware of the secrecy of the information they take whether or not those secrets were reasonably protected. It seems more logical to cabin the risk of liability for inadvertent misappropriation by imposing some kind of scienter requirement than through this kind of constructive notice through enforcement efforts. ${ }^{157}$

One author has argued that "[c] ourts should require firms to invest in precautionary measures until the marginal cost of those measures equals the marginal expected economic loss in the event of misappropriation." Note, Trade Secret Misappropriation: A Cost-Benefit Response to the Fourth Amendment Analogy, 106 Harv. L. Rev. 461, 473 (1992). But that makes no sense. It would essentially require dissipation of all the rents that might be gained from protecting trade secrets. Understanding that helps lead to the conclusion that any expenditure on secrecy is wasteful unless it serves some identifiable social purpose. 155 See, e.g., Harry Wingo, Dumpster Diving and the Ethical Blindspot of Trade Secret Law, 16 Yale L. \& Pol'y Rev. 195 (1997) (arguing that "dumpster diving" for discarded secrets should be illegal regardless of the efforts to prevent it, albeit on a "commercial morality" theory).

156 Rockwell, 925 F.2d at

157 Trade secret law does have such a requirement, though it rarely becomes an issue, probably 
Reasonable efforts to protect secrecy, then, may make sense as evidence of secrecy or even as evidence of scienter, but they probably don't make sense as a separate requirement. In this case it is the Restatements that have it right and the UTSA that has it wrong; both the Restatement of Torts and the Restatement of Unfair Competition treat reasonable efforts solely as evidence of secrecy, while the UTSA treats them as a separate condition for protection. ${ }^{158}$

\section{Contracting Around Trade Secret Law}

A second possible implication of an IP theory of trade secret rights involves efforts to contract around those rights. Just as treating trade secrets as IP rights makes preemption of conflicting tort laws more feasible by highlighting the policy purposes trade secret laws serve, it raises the question of whether trade secret rules are merely default rules that the parties can contract around, or whether they are policy judgments that courts should not allow the parties to undermine. There is a similar debate in copyright law, where courts have split on the question of whether parties can contract to prevent reverse engineering of software despite copyright rules that make reverse engineering legal under most circumstances. ${ }^{159}$ In trade secret law, this comes

because the requirement of misappropriation by improper means limits the number of cases in which defendants act in good faith but still meet the test for infringement. See Rohm \& Haas Co. v. Adco Chem. Co., 689 F.2d 424 (3d Cir. 1982) (imposing a negligence requirement as to whether the information taken constituted a secret); Pooley, supra note _, sec. 6.04[1], at 6-30 ("Knowledge on the part of the defendant is an element of liability for misappropriation.").

${ }_{158}$ Restatement of Torts Restatement (Third) of Unfair Competition sec. 39, cmt. g ("precautions taken to maintain the secrecy of information are relevant in determining whether the information qualifies for protection as a trade secret," but "if the value and secrecy of the information are clear, evidence of specific precautions taken by the trade secret owner may be unnecessary."); Restatement of Torts sec. $757 \mathrm{cmt}$. (including "the extent of measures taken by the claimant to guard the secrecy of the information" among six factors to be considered in determining whether information is secret). Compare UTSA sec. 1(4)(ii) (requiring "efforts that are reasonable under the circumstances to maintain secrecy" as an element of proof of a trade secret).

159 On the copyright rule permitting reverse engineering, see, e.g., Sega Ents. v. Accolade Inc., 
up in three significant contexts: efforts to contract around the requirement of secrecy itself, ${ }^{160}$ efforts to ban reverse engineering by contract, ${ }^{161}$ and the question of whether confidential relationships can be implied absent a contract. ${ }^{162}$ In each case, there are substantial policy interests that underlie the choice of trade secret rules. Indeed, in the case of secrecy itself, they are fundamental to the point of trade secret law. Accordingly, my inclination is to prevent parties from opting out of particular rules of trade secret law, at least to the extent they rely on

977 F.2d 1510 ( $9^{\text {th }}$ Cir. 1992); Sony Comp. Ent. v. Connectix Corp., 203 F.3d $596\left(9^{\text {th }}\right.$ Cir. 2000); Julie E. Cohen, Reverse Engineering and the Rise of Electronic Vigilantism: Intellectual Property Implications of "Lock-Out" Programs, 68 S. Cal. L. Rev. 1091 (1995); Philip J. Weiser, The Internet, Innovation, and Intellectual Property Policy, 103 Colum. L. Rev. 534 (2003). On the question of whether parties can contract around this rule, compare Vault v. Quaid, 847 F.2d 255 (5 ${ }^{\text {th }}$ Cir. 1988) (no); with Davidson \& Assocs. v. Jung, 422 F.3d 630 ( $^{\text {th }}$ Cir. 2005) (yes); Bowers v. Baystate Techs., 320 F.3d 1316 (Fed. Cir. 2003) (yes). See Mark A. Lemley, Beyond Preemption: The Law and Policy of Intellectual Property Licensing, 89 Calif. L. Rev. 111 (1999).

160 Compare Celeritas Techs. v. Rockwell Int'l Corp., 150 F.3d 1354 (Fed. Cir. 1998); Bernier v. Merrill Air Engineers, 770 A.2d 97 (Me. 2001) (employee violated nondisclosure agreement by publishing non-secret information); Simplified Telesys, Inc. v. Live Oak Telecom, LLC, 68 S.W.3d 688, 693-94 (Tex. App. 2000); Warner-Lambert Pharm. Co. v. John J. Reynolds, Inc., 178 F. Supp. 655 (S.D.N.Y. 1959) (parties could agree to treat information as a secret even after it was published) with Gary Van Zeeland Talent, Inc. v. Sandas, 267 N.W.2d 242 (Wisc. 1978); Sarkes Tarzian, Inc. v. Audio Devices, Inc., 166 F. Supp. 250 (S.D. Cal. 1958), aff'd, 283 F.2d 695 (9 $9^{\text {th }}$ Cir. 1960); American Paper \& Packaging Prods. v. Kirgan, 228 Cal. Rptr. 713,717 (Cal. Ct. App. 1986) ("An agreement between employer and employee defining a trade secret may not be decisive in determining whether the court will so regard it."); Electro-Craft Corp. v. Controlled Motion, Inc., 332 N.W.2d 890, 903 (Minn. 1983) (same). For detailed discussion, see Sandeen, Contract, supra note _, at 119.

161 See, e.g., Technicon Data Sys. Corp. v. Curtis 1000 Inc., 244 U.S.P.Q. 286 (Del. Ch. 1984); Data Gen. Corp. v. Digital Comp. Controls, Inc., 357 A.2d 105 (Del. Ch. 1975). For discussion, see Rice, supra note _, at 623-25 (arguing for preemption of restrictions on the reverse engineering of trade secrets in most cases).

162 See, e..g, Smith v. Dravo Corp., 203 F.2d 369 ( $7^{\text {th }}$ Cir. 1953) (implying confidential relationship between negotiating parties absent any confidentiality agreement); Phillips v. Frey, 20 F.3d 623, 631-32 (5 $5^{\text {th }}$ Cir. 1994) (same); but see Bateman v. Mnemonics, Inc., 79 F.3d 1532 $\left(11^{\text {th }}\right.$ Cir. 1996) (court "wary" of implied confidential relationships because of the potential for abuse); cf. Omnitech Int'1 v. Clorox Co., 29 U.S.P.Q.2d 1665 (5 $5^{\text {th }}$ Cir. 1994) (not illegal for company to use trade secret to evaluate company for purchase where parties didn't sign nondisclosure agreement). 
trade secret rather than contract remedies. ${ }^{163}$ This limits the power of trade secret owners in some cases - reverse engineering and secrecy - but strengthens their power in others - implied confidential relationships. Understanding trade secrets as IP rights won't resolve this debate, any more than it has in the copyright context. But it will make it clear that there must be a debate, and that it must be conducted with trade secret policy in mind. And it may strengthen the hand of those who argue that there is more at stake here than just the agreement of two private parties. ${ }^{164}$

\section{IP, Property, and "Absolute Dominion"}

Third, the theoretical underpinnings of trade secret law bear on the relationship between the IP conception of trade secrets and the freedom of others to use information to compete. A number of scholars suggest that conceiving of trade secrets as property rights will lead to stronger protection for trade secrets, at the expense of employee mobility and robust competition, and perhaps even of free speech. ${ }^{165}$ Conceiving of trade secrets as IP rights may affect the way

163 As Jim Pooley puts it, "The law relating to trade secrets reflects a balance of public and private interests in the encouragement of innovation, the preservation of ethics and the maintenance of a free marketplace of ideas and movement of labor. This balance should not be upset in any given transaction by private understandings between the parties."). Pooley, supra note _, sec. 3.04[3], at 3-39 to 39. See also 1 Milgrim, supra note _, at sec. 4.02[1][b] ("The mere presence of a confidentiality agreement does not elevate nontrade secret matter to trade secret status."); Restatement (Third) Unfair Comp. L. sec. 41, cmt. d, at 472; Rice, supra note , at 623 .

See, e.g., Alan E. Garfield, Promises of Silence: Contract Law and Freedom of Speech, 83 Cornell L. Rev. 261, 303-06 (1998).

165 See, e.g., Simpson, supra note _ ; Geraldine Szott Moohr, The Problematic Role of Criminal Law in Regulating the Use of Information: The Case of the Economic Espionage Act, 80 N.C. L. Rev. 853 (2002); Pamela Samuelson, Principles for Resolving Conflicts Between Trade Secrets and the First Amendment, 58 Hastings L.J. 777, 807 (2007). 
that other laws, such as antitrust, interact with trade secrets. ${ }^{166}$ Others worry that a property conception of trade secrets - and perhaps therefore an IP conception - will cause courts to gloss over the First Amendment and afford less protection to journalists or whistleblowers. ${ }^{167}$ In fact, however, I suggest in this paper that conceiving of trade secrets as IP rights has the opposite effect - it encourages courts to focus on the requirements and limits of trade secret law, particularly when compared to the standardless theories of unfair competition and unjust enrichment that seem the most obvious alternatives. ${ }^{168}$ In doing so, it is more likely to promote economic efficiency than any competing approach. ${ }^{169}$ Nor does conceiving of trade secrets as IP rights mean that they are unlimited, or that the First Amendment must give way. ${ }^{170}$

\section{How Long Does Secrecy Last?}

The final implication is also the most speculative: it may be that an IP theory of trade secrets suggests that there should be a term limit on trade secret protection. Patents and (at least until recently) copyrights expire after a set term of years. Trade secrets, by contrast, are protected for an indefinite term, until they are no longer secret. ${ }^{171}$ The theory is that the

166 For example, Katarzyna Czapracka suggests that the EU antitrust authorities give less deference to trade secret claims than their US counterparts because the EU has no conception of trade secrets as property rights. Katarzyna A. Czapracka, Antitrust and Trade Secrets: The U.S. and the EU Approach, 24 Santa Clara Comp. \& High Tech. L.J. 207 (2008).

167 On the potential for conflict between trade secrets and the First Amendment, see, e.g., Mark A. Lemley \& Eugene Volokh, Freedom of Speech and Injunctions in Intellectual Property Cases, 48 Duke L.J. 147, 229-32 (1998); Pamela Samuelson, Principles for Resolving Conflicts Between Trade Secrets and the First Amendment, 58 Hastings L.J. 777 (2007).

168 Accord Graves, supra note _.

169 Chally, supra note _, at 1280-82.

170 Lemley \& Volokh, supra note _, at 182-85 (debunking the argument that "property" is entitled to any special deference under the First Amendment).

171 See Merges et al., supra note _, at 58. 
possibility of publication of the secret, whether by malfeasance or by independent development or reverse engineering, means that the secret is fragile, and that over time it is likely to be revealed to the world. But it is not clear that this indefinite term properly strikes the balance between providing incentives to invent and ensuring that the world benefits from the new invention. It may be that after a certain period of time the additional incentive from the prospect of secrecy is marginal, while the costs of maintaining secrecy are not. Coca-Cola, for example, surely did not count on over a century of trade secret protection when it made the choice between patent and trade secret law. One possible implication of treating trade secrets as IP rights, then, is that the law should provide that trade secrets "expire" after a certain period. ${ }^{172}$ Certainly, an IP view of trade secret rights requires us to give thought to striking the right balance to encourage innovation without unduly limiting disclosure, a question that - whatever its proper resolution - might not arise at all under a different conception of trade secrecy.

\section{Conclusion}

Trade secrets are IP rights. They serve the same purposes as patent and copyright law they encourage innovation and the disclosure and dissemination of that innovation, though they sometimes serve those purposes in surprising ways. Trade secret law reduces investments in secrecy and encourages the dissemination of the secret to more people who can make productive use of it. Indeed, trade secret rights may serve the purposes of IP law better than more traditional IP rights, at least for certain classes of inventions. The public disclosure function of the patent system doesn't work very well in most industries, and doesn't work at all if inventors opt out of

172 Cf. Simpson, supra note _ , at 1156-58 (arguing for an defense applicable to secrets that cannot be reverse-engineered, and so might last forever). This isn't a necessary implication; trademarks are similarly protected for an indefinite term so long as they are used in commerce 
the patent system.

Understanding trade secrets as IP rights allows them to take their proper place in the pantheon of social policy designed to encourage innovation. It also gives us a way to think about how those rights are designed, a way that has significant implications for how trade secret law looks and how it interacts with other laws. Most surprisingly, those implications are ones that offer greater, not lesser, latitude for competitors and departing employees than the unfair competition rationale most commonly articulated as an alternative.

and renewed every ten years. 15 U.S.C. sec. 1059. 